\title{
Does the Land Price Subsidy Still Exist against the Background of Market Reform of Industrial Land?
}

\author{
Lin Zhang *, Yiting Zhao, Yuan Liu and Jinfang Qian
}

check for updates

Citation: Zhang, L.; Zhao, Y.; Liu, Y.; Qian, J. Does the Land Price Subsidy Still Exist against the Background of Market Reform of Industrial Land? Land 2021, 10, 963. https://doi.org/ 10.3390/land10090963

Academic Editor: Hossein Azadi

Received: 8 August 2021

Accepted: 9 September 2021

Published: 12 September 2021

Publisher's Note: MDPI stays neutral with regard to jurisdictional claims in published maps and institutional affiliations.

Copyright: (c) 2021 by the authors. Licensee MDPI, Basel, Switzerland. This article is an open access article distributed under the terms and conditions of the Creative Commons Attribution (CC BY) license (https:// creativecommons.org/licenses/by/ $4.0 /)$.
School of Economics and Management, Dalian University of Technology, Dalian 116024, China; Zhaoyiting926@mail.dlut.edu.cn (Y.Z.); jehovah@mail.dlut.edu.cn (Y.L.); Judy_JF@mail.dlut.edu.cn (J.Q.)

* Correspondence: zhanglin@dlut.edu.cn

\begin{abstract}
In 2007, China started the market reform of industrial land, with the aim of establishing a more effective industrial land market and promoting the effective allocation of land. For this study, we want to explore what strategic choices local governments and enterprises will make under the background of market-oriented reform, and whether there are still some implicit land price subsidies. In this context, based on matching micro land transfer data (2007-2013), we examined the policy effect in the seven years since the reform. Then, we further analyzed the land transfer strategies of local governments and the differences they made to enterprises' land purchasing decisions against the background of the reform. The following were found: (1) With the deepening of market reform, the effect has gradually become clear. The proportion of industrial land transferred through market modes increases year by year. Furthermore, due to marketization, the price of industrial land has increased significantly, and land purchases among enterprises have become more competitive. (2) Against the background of the reform, local governments tend to adopt listing as an alternative to negotiation, so as to attract investment from preferred enterprises. (3) Local governments tend to give state-owned and large or medium enterprises more subsidies by way of listing, which reduces the land purchase price for these enterprises. Based on the results, the market-oriented reform of land should be adhered to, and the selection mechanism of tender, auction, and listing transfer methods should be further standardized and refined. Besides, a variety of ways to meet the needs of enterprises for land use (such as lease first and then transfer) should be proposed to compensate for the existing insufficiency.
\end{abstract}

Keywords: land; price subsidy; market reform; local governments; industrial enterprise

\section{Introduction}

After a period of rapid development, China's industrialization process has entered the transformation stage from quantity growth to quality improvement. In this process, as a basic factor of production, the optimal allocation of industrial land is undoubtedly an important way to achieve industrial upgrading, alleviate resource bottlenecks, and promote economic growth [1]. Therefore, the central government began to implement the market reform of industrial land in 2007, and then made relevant policies to promote it several times. With the reform gradually deepening, market allocation of land is becoming more important. In 2020, China released guidelines on improving the market-based allocation of production factors and promoting the market-based allocation of land factors. In May 2020, China released guidelines to accelerate the improvement of the socialist market economy in the new era, further emphasizing the need to build a more complete marketbased allocation system for factors of production. Based on this, by summarizing and conceptualizing, the country can continue to push the reform in a reasonable direction.

The research on the optimal allocation of industrial land and the price of industrial land can be traced back to 1950s and 1960s. According to Alfred Weber's theory of the location of industries, transportation cost is an important condition for the location of 
industries, and industries usually choose the location where the transportation cost of raw materials and final products is the lowest [2]. Accordingly, the study of allocation of industrial land mainly focuses on the comprehensive analysis method of variable cost of industrial location selection $[3,4]$. Location condition is the most basic factor that affects the price of industrial land, including highways and distance to commercial areas $[5,6]$. With the deepening of research, the development of industry cluster theory makes people more aware of the impact of external macro environment on the allocation of industrial land, including industrial cluster and market environment. Among macro factors, policy factor is one of the key factors affecting the allocation of industrial land in China.

The primary effect of market reform is to directly change the transfer mode of industrial land. Before the reform, local governments had great decision power in the transfer of industrial land by means of allocation first and then negotiation. Therefore, driven by regional economic performance and the scheme of official promotion, local governments tended to lower industrial land prices to attract investors [7]. On the one hand, this caused a price distortion of land factors, which affected the effective allocation of land. On the other hand, it also affected the ability of many small-sized enterprises to compete competitively. After the reform, the central government required that industrial land should be transferred through market-based modes (tender, auction, and listing), thus weakening the ability of local governments to engage in land transfer and enhancing the freedom and competitiveness of enterprises when competing for land. At the same time, the pressure of local government promotion still exists. As an important factor of production, industrial land is still one of the instruments for local governments to attract investors. Then, against the background of reform, do land price subsidies still exist? What kind of strategic choices will local governments make? At the same time, what kind of land purchase decisions will enterprises make? Clarifying this problem will be of great significance to further deepen the reform.

At present, research on the land transfer decisions of local governments is mainly divided into two categories. The first kind of research mainly uses negotiation as the direct mode of government intervention in land transfer, finding that the quality of investment by means of negotiation is low. Furthermore, the distortion of land prices will lead to serious misallocation of land resources, which will have a negative impact on industrial development and upgrading [8-10]. However, this kind of research ignores the different land transfer behaviors of local governments under marketization, and regards tender, auction, and listing as equivalent modes of land transfer. In actual transactions, the government's choice of one of these three ways is quite different. The other kind of research mainly focuses on comparing market-based transfer modes and finds that compared with fully market-oriented auction, the marketization degree of listing is relatively weak. When land is transferred through listing, there is room not only for collusion and corruption between governments and enterprises, but also some implicit land price subsidies [11-13]. However, this kind of research lacks targeted analyses of the industrial land market and mainly uses statistical data for analysis. Therefore, the research fails to dig deeper and compare the characteristics of competitive land decisions at the micro level.

In this context, this paper focuses on the "implicit land price subsidy" under the background of the market-oriented reform of industrial land. It should be noted that due to the relatively backward of market-oriented reform of industrial land, there has been a strong land price subsidy behind the negotiated transfer of industrial land for a long time. After the market-oriented reform, although the behavior of transferring industrial land by negotiation is reduced, and local governments must transfer industrial land by marketoriented methods, there is a certain price gap between the listing which accounts for the largest proportion and the highest frequency of use and the auction (fully market-oriented). The "implicit land price subsidy" referred to in this paper is the land price subsidy behavior reflected behind the special way of listing.

Therefore, we first match the database of Chinese industrial enterprises (2003-2013) with the database of industrial land transfer (2007-2019) to construct a land purchase 
database of industrial enterprises (2007-2013), in order to break through the data bottleneck and research problems at the micro level. ${ }^{1}$ Then we discuss the influence of the land transfer mode on land prices, the government's strategic choice of land transfer mode against the background of reform, and the influence of this strategic choice on land purchase decision of enterprises.

The contributions of this paper are as follows: (1) By subdividing tender, auction, and listing, we verify the implicit subsidy effect of land prices based on listing. (2) Using micro data, the research perspective is extended to the enterprise level, and land purchasers are included in the analysis, so as to comprehensively consider the impact of the transfer strategies of those who supply land (local governments), the characteristics of those who demand land (industrial enterprises), and the characteristics of the bidding objects (industrial land) on the land purchase decisions of enterprises. (3) Listing is a land transfer mode with Chinese characteristics. The research in this paper is helpful to better understand the mechanism behind listing and supplement the research content of auction theory. (4) Market allocation of factors has always been an important reform area in China. Because the market reform of industrial land lags behind, there is still room for improvement in the current transfer mechanism of industrial land. This study can contribute to further understanding of the two-way relationship between local governments and enterprises under the market reform, and provides support for improving the market-based allocation mechanism of industrial land.

\section{Background of Land Market Reform}

With the reform of China's land system, the way enterprises acquire land has gradually changed from the initial allocation to market mode. At the beginning, against the background of a planned economic system, China gradually nationalized land by means of redeemable purchase, etc., forming the mode of a free and indefinite land supply that was uniformly allocated by the government, and based on this, the country's industrial and urban systems were established. However, this ignores the value of land factors, so that enterprises can only obtain land by means of allocation, which leads not only to the lack of autonomy in the choice of land purchase, but also to the loss of income from land resources.

After the reform and opening up, China gradually carried out a reform of the land use rights system, recognizing the importance of the commodity value of land in the process of transferring land use rights. However, with the acceleration of industrialization, the demand for land by all kinds of enterprises has greatly increased, and the act of transferring industrial land by negotiation has become more intense. Local governments tended to choose enterprises that were conducive to the rapid growth of fiscal revenue and short-term economic indicators, and gave them opportunities to purchase land through negotiation, which greatly reduces the degree of competition in the industrial land market [14]. To regulate the land market and improve the efficiency of land allocation, on 23 December 2006, China issued the "Notice on the issuance and implementation of the national minimum price standard for the transfer of industrial land". This policy stipulated that industrial land must be transferred by means of "tender, auction or listing", and that the transfer reserve price and transaction price should not be lower than the corresponding minimum standard price for local land. From this, the market reform of industrial land formally began.

Since 2007, the proportion of industrial land transferred through negotiation has decreased year by year, and the degree of marketization has continuously strengthened. In $2007,27.62 \%$ of the industrial land in China was transferred through market-based modes, and in 2019 , the proportion rose to $93.65 \%$. At present, in addition to negotiation, local governments can choose tender, auction, or listing according to land supply policies, land use, planning restrictions, and other factors. According to the income equivalence principle of auctions, when the participants conform to the basic hypothesis, the expected revenue of a single item at auction under different auction mechanisms is equal $[15,16] .^{2}$ However, in the Chinese land transfer market, these assumptions are not entirely valid. Because the local government is still the main decision maker in the transfer of industrial land, in the 
case of information asymmetry, the different degrees of competition among tender, auction, and listing provide the conditions for local governments to strategically choose the transfer mode of investment.

Tender is a form of sealed auction. The bidding documents are sealed and put into a designated bidding box. After the opening bid, the winning bidder will be determined according the higher price, or the bid evaluation group will evaluate the bidding price and the development prospect and social responsibility of the bidding enterprise, and recommend the winning candidate. Then, the tenderer will determine the final winning bidder. However, this mode is mainly applicable to large-scale construction land, so it is used infrequently. Different from tender, auction and listing are types of ascending, or English auction. Competitive enterprises in an auction bid together, and the highest price determines the winner. A listing is a two-stage auction, with the first stage of sequential bidding and the second stage of on-site bidding [17]. Between auction and listing, enterprises can obtain relevant information and observe the bids and strategic choices of others, so as to effectively reduce the cost of information and ultimately increase the expected income of the transferor (the local government).

In an English auction, the information acquisition process will delay the enterprise's exit decision and improve the final transaction price. Relevant studies also prove that compared with a static auction, in an English auction, because bidders can observe the quantity of bids and bidding information of competitors, the competition is more intense and the prices are relatively higher $[18,19]$. Although some studies have found that there is a certain excessive information acquisition behavior at English auctions and the timing of information acquisition is not appropriate when the cost of acquisition is high, in general, the transfer of industrial land through auction is still considered to be the most competitive form [20]. Various types of enterprises can make competitive land decisions openly and transparently. The existing research also regards auction as a more market-based form of transfer, with the belief that the government has a low degree of intervention in the process $[21,22]$. From the perspective of proportions, this method is not favored by local governments. According to the amount of industrial land transferred by the different modes (Figure 1), less than $10 \%$ of industrial land has been transferred through auction every year since the market reform of industrial land in 2007.

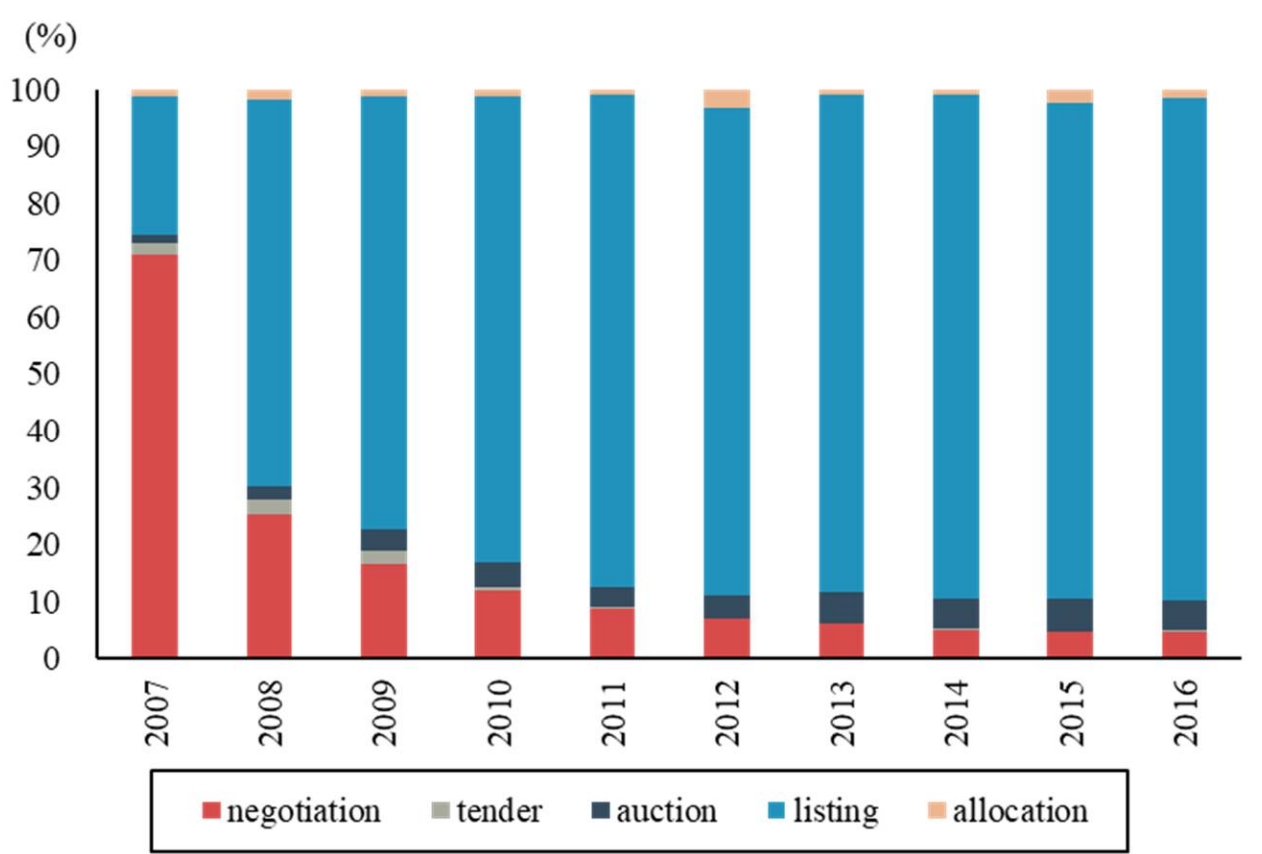

Figure 1. Amount of industrial land transferred by different modes. ${ }^{3}$ Data source: Chinese land market network (http:/ / www.landchina.com/ accessed on 30 July 2020). 
Compared with tender and auction, listing is more widely used. Under the twostage transfer method of listing, the government department first publishes the relevant information of the place being listed, and eligible bidders can fill in the form with quotes accordingly. After the listing period expires, the highest quote will be announced. If there are still bids from bidders, the second stage of on-site bidding will proceed. Theoretically, listing fully combines the multiple characteristics of tender and auction, so it is more suitable for Chinese industrial land transactions. The research also proved that, on the assumption that both professional and non-professional bidders existed, a listing could provide more information for bidders compared with an auction, thus leading to higher final transaction prices [23]. However, beyond the completion of many industrial land transfers through listing, its unique two-stage auction mode also provides a certain space for local governments to intervene in the transfer of industrial land [24].

The research shows that listing is a transfer mode between non-marketization and complete marketization. In the listing process, on the one hand, enterprises can cooperate with the government in advance, prioritize quotes in order to send a signal to other bidders, and finally squeeze out potential competitors and reduce the cost of competition. On the other hand, because there is no restriction on the number of bidding enterprises in listing, as long as they meet the lowest standard, even if there is only one company, it also can make a deal. Therefore, local governments can set qualification conditions in the first phase of bidding, limiting the participation of potential bidders, so that preferred enterprises can obtain land at a lower price $[11,12,25]$. It can be seen from Figure 1 that local governments show a great tendency to use listing, at a rate of more than $90 \%$. Figure 2 shows that the average price of land transferred through listing is lower than that through tender and auction all year round, which supports the conjecture that there is land intervention behavior when local governments transfer land through listing.

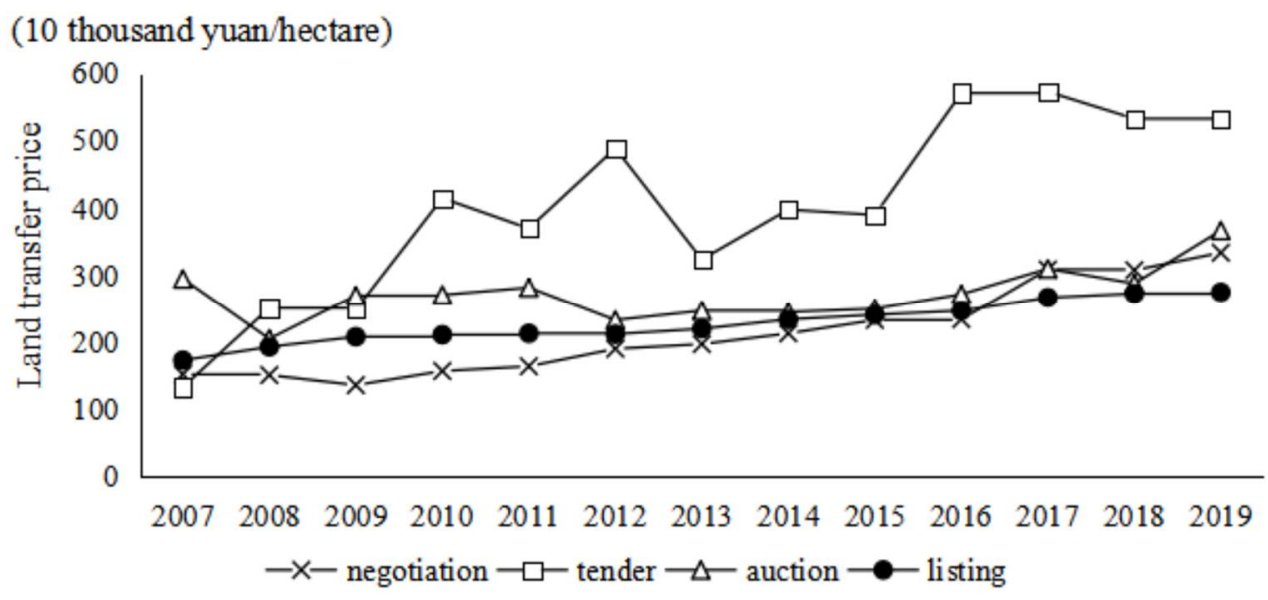

Figure 2. Price of industrial land transferred by different modes. ${ }^{4}$ Data source: Chinese land market network (http:/ / www.landchina.com/ accessed on 30 July 2020).

According to the above literature review and statistical analysis, this paper posits that against the background of market reform, local governments can provide certain land price subsidies for preferred enterprises by using the unique bidding process of listing, so as to achieve the purpose of attracting investors.

\section{Theoretical Analysis and Hypotheses}

\subsection{Market-Based Transfer and Land Purchase by Enterprises}

For a long time, because their promotion opportunities are closely related to local economic performance, government officials have tended to introduce projects that can greatly improve local economic growth in the short term, and industrial land, as the most basic production factor of enterprise production, has become a target of fierce competition. Local governments attract investors by agreeing to transfer industrial land at low prices, 
so as to improve the performance indicators of their respective region [26,27]. Especially since the Tax Sharing Reform in 1994, the financial pressure of local governments has been increasing. The transfer of industrial land can not only raise transfer fees but also provide long-term future tax payments for the government [28-30]. Therefore, the supply of industrial land has been in a non-public state of low-price negotiation and industrial land transfer has been regarded as a synonym for low-price land supply for a long time.

Compared with non-market-based transfer, market-based transfer introduces the competition mechanism into the transaction process, which increases previously low industrial land prices to gradually approach the real value of land factors, thus reflecting the real state of market supply and demand and realizing a reasonable allocation of factors [22]. In addition, according to the theory of factor allocation, the purchase of land through market modes is conducive to forming an open, effective land transfer process and reducing rent-seeking behavior of enterprises. Thus, it provides a competitive space for more types of enterprises, and land can be acquired by market- and profit-oriented enterprises [31]. Studies have shown that the market-based transfer mechanism can limit the occurrence of illegal acts in land transfer and provide an environment for enterprises to compete for land freely [32]. Based on the analysis mentioned above, we propose the following hypothesis:

Hypothesis 1. Market-based transfer modes increase the price of industrial land and strengthen the willingness of enterprises to compete for land.

\subsection{Local Governments' Strategic Choice for Market-Based Transfer Mode}

Since the market reform of industrial land, local governments have to follow the instructions of the central government and transfer industrial land through tender, auction, or listing. As mentioned in Hypothesis 1, this change of transfer mode, by introducing a competition mechanism into the land transfer market, improves the space for enterprises to compete freely for land and reduces the government's excessive intervention in the industrial land market. However, this change is limited to the land market and does not fundamentally address the reasons for the low price of land supply by local governments, that is, the promotion scheme and the demand for investment. For local governments, it is still an important way to attract preferred enterprises to invest with certain land price subsidies, while for enterprises, the goal of production and operation is to maximize profits. Under the market reform, the cost of land has increased. Especially in the current environment of rising labor costs, enterprises expect preferential support policies from the government and to obtain certain land price subsidies to reduce production costs. Therefore, under the conditions of the market transfer policy, local governments try to use their role as land suppliers to intervene in land transfers. Listing is relatively less market-based, and thus becomes the first choice of the government.

Next, in order to investigate the land intervention behavior of local governments when faced with investment demand, we further added capital investment to the analytical framework, based on the urban economic model [12,33]. The decision-making behaviors of the local government, the original land owner, and the land purchasing enterprise are analyzed. The number of external enterprises in a city is $M$ and the number of general enterprises is $N$. Between them, external enterprises have a strong spillover effect and positive externality, which can bring more output growth to the city, while the externality of general enterprises is assumed to be 0 . In order to focus on capital and land factor investment, we assume that the urban production function is:

$$
Y=A K^{\propto} T^{\beta} M^{\varepsilon}
$$

where $\alpha, \beta$, and $\varepsilon$ are all positive and $0<\alpha+\beta+\varepsilon<1$; $A$ represents the resource owned by the city; $K$ represents the input of capital factors; $T$ represents the input of land factors, referring to the input of industrial land; and $M^{\varepsilon}$ represents the positive externality brought by the external enterprises. 
In the transfer process of urban industrial land, the local government first expropriates $T$ units of land from the original owner at a cost of $P_{0}$ for each unit, and then transfers the land to the preferred enterprise in the form of industrial land at a price of $P$ per unit. Suppose that the government's fiscal revenue consists of land transfer revenue and fiscal expenditure, which consists of infrastructure construction, land acquisition costs, and land price subsidies. Among them, infrastructure construction is related to urban land supply, denoted as $\theta T$, and $0<\theta<1$. The government's land acquisition cost is $P_{0} T$. In order to attract investment from enterprises, the government provides a land price subsidy for external enterprises, $H_{m}$, and for general enterprises, $H_{n}$. Thus, the budget constraint of the government for the balance of payments is:

$$
P T=\theta T+P_{0} T+H_{m} M+H_{n} N
$$

Here we mainly consider the compensation income of the original land owner and assume that they spend all of this money on expenditures. Thus, the budget constraint of the original land owner is:

$$
P_{0} T=C
$$

where $P_{0} T$ represents the income earned from the sale of $T$ units of land and $C$ represents expenditures.

Next, we consider the production decisions of enterprises. Referring to the setting described by Wang and Yang (2016), it is assumed that the production capacity of enterprises is the same; then the production function of the enterprise is:

$$
y=\frac{Y}{M+N}=\frac{1}{M+N} A K^{\alpha} T^{\beta} M^{\varepsilon}=(M+M)^{\beta-1} A K^{\alpha} t^{\beta} M^{\varepsilon}
$$

Here, $t$ is the input amount of land factors of a single enterprise, and it satisfies $T=(M+N) t$. According to this production function, the equilibrium price of industrial land purchased by the enterprise should be equal to the marginal output of the land. Therefore, the equilibrium price of industrial land is:

$$
P=\frac{\partial y}{\partial t}=\beta(M+N)^{\beta-1} A K^{\alpha} t^{\beta-1} M^{\varepsilon}=\beta A K^{\alpha} T^{\beta-1} M^{\varepsilon}
$$

In order to simplify the analysis, it is assumed that product and capital are unit prices; then, the profit of one enterprise is:

$$
G=y-P\left(\frac{T}{M+N}\right)=\frac{1-\beta}{M+N} A K^{\alpha} T^{\beta} M^{\varepsilon}=\frac{1-\beta}{M+N} Y
$$

Since officials of local governments are somewhat self-interested, we assume that their utility consists of political promotion and the welfare of original land owners. In China, the political promotion of local officials is mainly related to economic growth indicators. Officials pursue the rapid growth of economic indicators and consider the transfer of industrial land as an important tool to attract investment and bring about economic growth Therefore, $U_{1}=Y-M R-N V$ is used to measure the utility of political promotion of government officials, in which $R$ and $V(R>V)$ respectively represent the opportunity cost of external and general enterprises investing and setting up factories in cities. In addition to the utility brought by political promotion, government officials also need to consider changes in the welfare of original land owners during land expropriation [34]. It is assumed that an original land owner's utility is determined by his payout $C$, so $U_{2}=C$. Therefore, the ultimate objective function of local government officials is:

$$
\max U=Y+C-M R-N V
$$


In addition to Equations (2) and (3), the conditions also include the constraint conditions of investment. Since under the equilibrium condition of the free flow of enterprises, the profits and total subsidies of external and general enterprises should be equal to the opportunity cost of investment, we have:

$$
\begin{aligned}
& G+H_{m}=R \\
& G+H_{n}=V
\end{aligned}
$$

Based on these equations, the following can be obtained:

$$
\max U=2 A K^{\alpha}(M+N)^{\beta} t^{\beta} M^{\varepsilon}-\theta(M+N) t-2 M R-2 N V
$$

On the one hand, local governments need to take the perspective of public decisionmakers and decide on the optimal quantity of land supply to satisfy the production of enterprises and the welfare of original land owners. On the other hand, as mentioned above, against the background of promotion schemes and financial pressure, government officials can offer certain land price subsidies to enterprises through listing, so as to attract enterprises to invest and build factories. That is to say, local governments need to make decisions on the land transfer area, the number of enterprises entering the city, and the land price subsidies under their own constraints and those of the original land owners and the enterprises, so as to maximize the utility. Thus, the following can be obtained:

$$
\begin{gathered}
\frac{\partial U}{\partial t}=2 \beta A K^{\alpha}(M+N)^{\beta} t^{\beta-1} M^{\varepsilon}-\theta(M+N)=0 \\
\frac{\partial U}{\partial M}=2 A K^{\alpha} t^{\beta}\left[\beta(M+N)^{\beta-1} M^{\varepsilon}+\varepsilon(M+N)^{\beta} M^{\varepsilon-1}\right]-\theta t-2 R=0 \\
\frac{\partial U}{\partial N}=2 \beta A K^{\alpha} t^{\beta}(M+N)^{\beta-1} M^{\varepsilon}-\theta t-2 V=0
\end{gathered}
$$

According to Equations (11)-(13), we have:

$$
\begin{gathered}
T=(2 \beta)^{\frac{1}{1-\beta}} A^{\frac{1}{1-\beta}} K^{\frac{\alpha}{1-\beta}} M^{\frac{\varepsilon}{1-\beta}} \theta^{\frac{1}{\beta-1}} \\
R=A K^{\alpha} t^{\beta}(M+N)^{\beta} M^{\varepsilon}\left(\frac{\beta}{M+N}+\frac{\varepsilon}{M}\right)-\frac{\theta t}{2}=A K^{\alpha} T^{\beta} M^{\varepsilon}\left(\frac{\beta}{M+N}+\frac{\varepsilon}{M}\right)-\frac{\theta T}{2(M+N)} \\
V=A K^{\alpha} t^{\beta}(M+N)^{\beta} M^{\varepsilon}\left(\frac{\beta}{M+N}\right)-\frac{\theta t}{2}=A K^{\alpha} T^{\beta} M^{\varepsilon}\left(\frac{\beta}{M+N}\right)-\frac{\theta T}{2(M+N)}
\end{gathered}
$$

According to Equation (14), it can be found that the optimal industrial land supply of local governments depends on the marginal output elasticity of land, the resources of the city, the input of capital factors, the number of external enterprises, and the proportion of infrastructure construction. In addition, if other conditions remain unchanged, local governments will increase the supply of industrial land when there is an increase in capital input or the number of external enterprises, which reflects the government's need to attract investment, that is, in order to attract enterprise investment, the transfer area of industrial land will be increased.

Combined with Equations (6), (8) and (9), we have:

$$
\begin{gathered}
H_{m}=A K^{\alpha} T^{\beta} M^{\varepsilon}\left[\frac{(2 \beta-1)}{(M+N)}+\frac{\varepsilon}{M}\right]-\frac{\theta T}{2(M+N)} \\
H_{n}=A K^{\alpha} T^{\beta} M^{\varepsilon}\left(\frac{2 \beta-1}{M+N}\right)-\frac{\theta T}{2(M+N)}
\end{gathered}
$$


By subtracting Equation (17) from Equation (18), we have:

$$
H_{m}-H_{n}=A K^{\alpha} T^{\beta} M^{\varepsilon} \frac{\varepsilon}{M}
$$

Due to the subsidy difference between external and general enterprises $\left(H_{m}-H_{n}\right)>0$, local governments will give more land price subsidies to external enterprises in order to attract them. At the same time, $\frac{\partial\left(H_{m}-H_{n}\right)}{\partial K}>0, \frac{\partial\left(H_{m}-H_{n}\right)}{\partial \varepsilon}>0$. It is further explained that the degree of subsidy largely depends on the contribution that enterprises can bring to the local economy. With increased capital input or output elasticity of external enterprises, they can bring more growth to the local economy, and the subsidy gap between them and general enterprises will further expand.

The above results confirm that local governments provide land price subsidies to external enterprises in order to attract investment. As mentioned above, among the three market-based modes of tender, auction, and listing, the two-stage transfer mode of listing provides more space for local governments to intervene. Therefore, we propose the following:

Hypothesis 2. In the context of market reform of industrial land, local governments tend to transfer industrial land through listing in order to attract investment.

\subsection{Strategic Choice of Market-Based Transfer Modes, Preferred Enterprises, and Land Price Subsidies}

The results of the above model indicate that local governments tend to transfer industrial land to external enterprises that can bring great improvements to the regional economy, and price subsidy is an important way for governments to attract investment from external enterprises. However, due to the information asymmetry between local governments and enterprises, it is difficult for governments to observe the real operating conditions of enterprises in the process of selecting preferred enterprises. In this context, the relationship between enterprises and government often affects the government's choice. Compared with other types of enterprises, state-owned enterprises not only bear the responsibility of social development and provide a large amount of taxes to the government, but also maintain close ties with the government, which gives them more opportunities to compete for land at lower prices than other enterprises. Relevant studies also show that state-owned enterprises have more advantages in obtaining land resources and corresponding price subsidies [28,35].

In addition to the government-enterprise correlation, the scale of enterprises is also an important reference index for the government. Larger enterprises tend to be capitalintensive, which not only can bring a large amount of fixed asset investment to the region in the short term and stimulate local economic growth, but also can provide a relatively stable long-term tax source to relieve the government's financial pressure [36]. Therefore, compared with small enterprises, large and medium-sized enterprises tend to enjoy more land price subsidies.

Based on the above analysis, we propose the following:

Hypothesis 3. Among enterprises of different types and scales, local governments have a higher tendency to attract state-owned and large or medium-sized enterprises to invest, and thus give them more land price subsidies.

\section{Research Design and Model}

\subsection{Data Source and Processing}

If we want to fully reveal the influence of local governments' land transfer behavior on land prices, we need to get micro data on land purchasing enterprises for analysis. At present, the research on industrial land is mostly limited by the acquisition of data; only macro data can be analyzed, and it cannot be implemented at the micro level. This is bound 
to affect the research accuracy. In order to solve this problem, we obtained micro data of industrial land transactions by matching two databases.

The basic database consists of two main databases. One is the database for the transfer of industrial land, announced by the Chinese land market network. Since the market reform in 2007, detailed information on each land transaction must be published on the network. We collected more than 430,000 pieces of data on industrial land transfer and result announcements provided by the network from 2007 to 2019. The indicators include land transfer mode, land source, land area, land price, and floor area ratio.

The second database is the database of Chinese industrial enterprises. It is released by the National Bureau of Statistics, which includes production and operation information on all state-owned industrial enterprises and non-state-owned industrial enterprises above a designated size, including current assets, fixed assets, long-term investments, and total industrial output value. Using this database, we collected basic information and financial data on Chinese industrial enterprises from 2003 to 2013. There were more than 300,000 enterprises in each year.

Combining the above information on industrial land transfers and industrial enterprises, ${ }^{5}$ we matched the two databases. If an enterprise purchases several plots of land in the same year, only the first purchase record will be kept according to the existing practice [34]. The land purchase database of industrial enterprises from 2007 to 2013 was finally obtained, and the total amount of data was more than 40,000 items, as shown in Table 1. In addition, in order to ensure the reliability of the data, we processed the data as follows. We drew lessons from the existing approach and excluded missing or non-positive data of the original fixed assets and net value of fixed and current assets, data on the indicator of fewer than eight employees, data on land area and prices that are not positive, and other key indicators of abnormal data [37].

Table 1. Sample size of database after matching.

\begin{tabular}{ccccccccc}
\hline Year & $\mathbf{2 0 0 7}$ & $\mathbf{2 0 0 8}$ & $\mathbf{2 0 0 9}$ & $\mathbf{2 0 1 0}$ & $\mathbf{2 0 1 1}$ & $\mathbf{2 0 1 2}$ & $\mathbf{2 0 1 3}$ & Sum \\
\hline Parcel number & 3569 & 3092 & 4204 & 3393 & 8924 & 10,019 & 11,042 & 44,243 \\
\hline
\end{tabular}

Based on the above data, in order to control the location characteristics of land, we supplemented the indicator of distance between the land and the city center (taking the old railway station as the city center coordinate and measuring with Google Maps). In addition, in order to control the influence of the regional economic environment, we matched the urban macroeconomic data in the statistical yearbook to the database as the control variables according to the city where the land is located.

\subsection{Variables and Models}

\subsubsection{Effect of Market-Based Transfer Mode on Land Prices}

First, Hypothesis 1, regarding the overall effect of market reform of industrial land on land prices, was tested. In this paper, the transfer modes are divided into market-based (tender, auction, and listing) and non-market-based (negotiation). We added dummy variables of the market-based transfer mode to observe their influence on the price of industrial land. The model is set as follows:

Model 1:

$$
\text { Inprice }_{i}=\beta_{0}+\beta_{1} \text { market }_{i}+\sum \beta_{i} \text { land_feature }_{i}+\varepsilon_{i}
$$

In model 1 , the dependent variable is the price of industrial land (lnprice). There is a scale effect in the transfer of land factors. With an increased number of deals, the per-unit land transfer price is gradually reduced, and it is difficult for the unit price to reflect the phenomenon. Therefore, in this paper, the logarithm of the total price of industrial land is selected as the dependent variable, and the indicator of land area is added into the model for control. The core independent variable is the indicator of market-based transfer mode 
(market). When land $i$ is transferred through the market-based mode, the indicator takes a value of 1 ; otherwise, the indicator takes a value of 0 .

In addition, land_feature represents the variables for land features, and is used to control the influence of other land factors on the land price, specifically including the internal features (parcel_area, Indistance, LFAR, HFAR, parcel_resource) and external features (region, InPGDP, industrial_structure, Intraffic, Inwage, expenditure) of the land.

\subsubsection{Local Government's Strategic Choice for Transfer Mode of Industrial Land}

Based on the regression of land prices, we further subdivided the three market-based transfer modes and constructed a multivariate logit model to test the local government's strategic choice among the three transfer modes. In the model, negotiation is taken as a reference variable, and the logarithmic probabilities of the three transfer modes relative to negotiation are estimated. If the probabilities are significantly different, it means that the local government has different preferences for the three market-based transfer modes. The model is set as follows:

Model 2:

$\ln \left(\frac{P\left(Y_{i}=k\right)}{P\left(Y_{i}=1\right)}\right)_{j}=\beta_{0}+\sum \beta_{j}$ firm_feature $_{j}+\sum \beta_{i k}$ land_feature $_{i}+\varepsilon_{i j k}(k=2,3,4)$

In this model, the dependent variable $\left(\ln \left(\frac{P\left(Y_{i}=k\right)}{P\left(Y_{i}=1\right)}\right)\right)$ represents the relative probability that land $i$ will be transferred by means of $k$ (tender, auction, listing), as compared to the transfer mode (negotiation). The core independent variable is firm_feature, which mainly includes type and scale. According to the above analysis, when local governments give certain land price subsidies, they often determine the preferred enterprises according to the degree of government-enterprise correlation or the scale of the enterprise. Therefore, we mainly selected two core indices of type and scale to investigate the land purchases of enterprises.

Regarding the types, enterprises are classified as state-owned enterprise, other mainland enterprise, enterprise from Hong Kong, Macao, or Taiwan (HKMT enterprise), or foreign enterprise. Regarding the scale, there are three main indicators to measure the scale of an enterprise: total assets, sales revenue, and number of employees. Among them, sales revenue is easily affected by market demand factors. Therefore, we chose to measure the scale of enterprises by total assets. According to the interim statistical classification method of small and large enterprises issued by the National Bureau of Statistics, an enterprise with total assets of 400 million yuan or more is classified as a large-scale enterprise, one with total assets of 40 million to 400 million yuan is classified as a medium-scale enterprise, and one with total assets less than 40 million yuan is classified as a small-scale enterprise. ${ }^{6}$ In addition, in the subsequent analysis of enterprises' willingness to bid, in order to avoid endogeneity, we measured the scale of enterprises by the number of employees (Inscale).

The variable land_feature was also added to the model as a control. However, it needs to be noted that since the dependent variable is the probability of the government's choice of transfer mode, some internal features of land, such as parcel_area, LFAR, and HFAR, have little influence on it, so they are not included in model 2.

\subsubsection{Effect of Strategic Choice of Transfer Mode on Land Purchases by Enterprises}

The selection probability model can only discuss the government's preferred transfer mode from the perspective of probability. In order to further investigate the differences in the influence of this behavior on land purchases by different enterprises and test whether the land price subsidy still exists, the three market-based transfer modes of tender, auction, and listing were added into the model as dummy variables. The influence of government land intervention is identified from the two aspects of land purchase price and willingness to bid. The models are as follows: 
Model 3:

$$
\begin{aligned}
\text { Inprice }_{i j}=\beta_{0}+ & \beta_{1} \text { transfer_mode }_{i}+\sum \beta_{j} \text { firm }_{-} \text {feature }_{j}+\sum \beta_{i} \text { land_feature }_{i}+\varepsilon_{i j} \\
& \text { Model } 4: \\
\text { lnwillingness }_{i j}= & \beta_{0}+\beta_{1} \text { transfer_mode }_{i}+\sum \beta_{j} \text { firm_feature }_{j}+\sum \beta_{i} \text { land_feature }_{i}+\varepsilon_{i j}
\end{aligned}
$$

The dependent variable in model 3 is the logarithmic value of the total price of industrial land (lnprice), and the indicator of land area is added into the model for control. The core independent variables include transfer_mode and firm_feature. Here, negotiation is regarded as the reference group, and the variables of tender, auction, and listing are added to observe the coefficients.

The dependent variable of model 4 is the enterprise's willingness to bid (Inwillingness). This variable mainly measures the land purchase price paid by the enterprise considering the capital constraint, and is calculated by the ratio of total land purchase price to current assets. Core independent variables still include transfer_mode and firm_feature. Since the variable of lnwillingness may be directly affected by current assets, in order to avoid error, we adopted the logarithm of the number of employees to directly measure the scale of enterprises in this part.

Tables 2 and 3 list the descriptions of variables and the descriptive statistics of contin-

\begin{tabular}{|c|c|c|c|}
\hline \multicolumn{3}{|c|}{ Variables } & Description (Unit) \\
\hline \multicolumn{2}{|c|}{ Dependent variables } & $\begin{array}{l}\text { lnprice } \\
\text { lnwillingness }\end{array}$ & $\begin{array}{l}\text { Uses total land price and its logarithmic form (10,000 yuan) } \\
\qquad \ln \text { (price/current assets) }(1 / 100,000 \text { yuan) }\end{array}$ \\
\hline \multirow{5}{*}{$\begin{array}{l}\text { Independent } \\
\text { variables }\end{array}$} & (1) transfer mode & $\begin{array}{l}\text { negotiation } \\
\text { tender } \\
\text { auction } \\
\text { listing }\end{array}$ & $\begin{array}{c}\text { Negotiation }=1 \text { if land transferred in this way; otherwise } 0 \\
\text { Tender }=1 \text { if land transferred in this way; otherwise } 0 \\
\text { Auction }=1 \text { if land transferred in this way; otherwise } 0 \\
\text { Listing }=1 \text { if land transferred in this way; otherwise } 0\end{array}$ \\
\hline & $\begin{array}{l}\text { (2) land internal } \\
\text { feature }\end{array}$ & $\begin{array}{l}\text { parcel_area } \\
\text { Indistance } \\
\text { LFAR } \\
\text { HFAR } \\
\text { parcel_resource }\end{array}$ & $\begin{array}{c}\text { Land area (hectare) } \\
\text { Distance of land from city center }(\mathrm{km}) \\
\text { Low floor area ratio } \\
\text { HFAR }=1 \text { if floor area ratio is high; otherwise } 0\end{array}$ \\
\hline & $\begin{array}{l}\text { (3) land external } \\
\text { feature }\end{array}$ & $\begin{array}{c}\text { region } \\
\text { InPGDP } \\
\text { industrial_structure } \\
\text { Intraffic } \\
\text { lnwage } \\
\text { expenditure }\end{array}$ & $\begin{array}{c}\text { Region } 1=1 \text { if land belongs to central region; otherwise } 0 \\
\text { Region } 2=1 \text { if land belongs to eastern region; otherwise } 0 \\
\text { Region } 3=1 \text { if land belongs to northeast region; otherwise } 0 \\
\text { Region } 4=1 \text { if land belongs to western region; otherwise } 0 \\
\text { Uses its logarithm ( } 10,000 \text { yuan/person) } \\
\text { Added value of secondary industry/third industry } \\
\text { Urban highway mileage/total number of people (km/10,000 persons) } \\
\text { Average wage (yuan) } \\
\text { Fiscal expenditure (GDP) }\end{array}$ \\
\hline & \multirow[t]{2}{*}{ (4) firm feature } & type & $\begin{array}{l}\text { state-owned enterprise }=1 \text { if enterprise falls into this type; otherwise } 0 \\
\text { other mainland enterprise }=1 \text { if enterprise falls into this type; otherwise } 0 \\
\text { HKMT enterprise }=1 \text { if enterprise falls into this type; otherwise } 0 \\
\text { Other foreign enterprise }=1 \text { if enterprise falls into this type; otherwise } 0\end{array}$ \\
\hline & & scale & $\begin{array}{l}\text { (1) In Model 3, scale of enterprises divided into large-scale, medium-scale, and small-scale } \\
\text { by total assets } \\
\text { (2) In Model 4, scale of enterprises measured by logarithm of number of people (lnscale) }\end{array}$ \\
\hline
\end{tabular}
uous variables.

Table 2. Variable descriptions.

Note: GDP deflator was used to reduce regional per capita GDP to the level in 2007; CPI deflator was used to flatten other price variables back to 2007 levels. 
Table 3. Descriptive statistics of continuous variables.

\begin{tabular}{|c|c|c|c|c|c|c|c|c|}
\hline \multirow{2}{*}{ Variables } & \multicolumn{4}{|c|}{2007} & \multicolumn{4}{|c|}{2013} \\
\hline & Mean & Sd & Min & Max & Mean & Sd & Min & Max \\
\hline Inprice & 5.5654 & 1.4242 & -0.9937 & 11.0979 & 5.7353 & 1.2283 & -0.1835 & 10.8648 \\
\hline Inwillingness & 9.4588 & 1.7158 & 2.5747 & 14.4012 & 9.1553 & 1.6177 & 1.3863 & 14.3896 \\
\hline parcel_area & 4.6005 & 12.1028 & 0.0055 & 503.8300 & 3.7002 & 6.6985 & 0.0047 & 235.0480 \\
\hline Indistance & 3.0938 & 1.0113 & -1.7720 & 6.2050 & 3.4607 & 0.8962 & -2.2073 & 6.7042 \\
\hline LFAR & 0.57091 & 0.4952 & 0.0000 & 8.0000 & 0.8252 & 0.3121 & 0.0000 & 7.0000 \\
\hline $\ln P G D P$ & 0.9557 & 0.7609 & -0.9007 & 3.4459 & 1.3485 & 0.6742 & -0.4038 & 3.6508 \\
\hline industrial_structure & 1.4148 & 0.5521 & 0.3722 & 7.0758 & 1.4458 & 0.5276 & 0.2904 & 6.7736 \\
\hline Intraffic & 3.0592 & 0.4217 & 2.0104 & 5.6761 & 3.2946 & 0.4192 & -0.2892 & 6.0931 \\
\hline lnwage & 10.0574 & 0.2920 & 9.4060 & 10.8059 & 10.5439 & 0.2089 & 9.9138 & 11.2741 \\
\hline expenditure & 0.1084 & 0.0387 & 0.0458 & 0.4334 & 0.1571 & 0.0724 & 0.0445 & 1.3684 \\
\hline
\end{tabular}

\section{Empirical Results}

\subsection{Effect of Market Reform on Industrial Land Prices}

First, based on model 1, we analyzed the impact of market-based transfer mode on industrial land prices against the background of reform. The regression results are shown in Table 4.

Table 4. Impact of market-based transfer modes on industrial land prices.

\begin{tabular}{|c|c|c|c|c|c|c|c|}
\hline Variables & (1) 2007 & (2) 2008 & (3) 2009 & (4) 2010 & (5) 2011 & (6) 2012 & (7) 2013 \\
\hline market & $\begin{array}{c}0.4376^{* * *} \\
(0.0440)\end{array}$ & $\begin{array}{c}0.6195^{* * *} \\
(0.0613)\end{array}$ & $\begin{array}{c}0.7967^{* * *} \\
(0.0698)\end{array}$ & $\begin{array}{l}0.7227^{* * *} \\
(0.0638)\end{array}$ & $\begin{array}{c}0.6218^{* * *} \\
(0.0581)\end{array}$ & $\begin{array}{c}0.5600^{* * *} \\
(0.0662)\end{array}$ & $\begin{array}{c}0.5265^{* * *} \\
(0.0541)\end{array}$ \\
\hline parcel_area & $\begin{array}{c}0.1004^{* * *} \\
(0.0077)\end{array}$ & $\begin{array}{c}0.1123^{* * *} \\
(0.0098)\end{array}$ & $\begin{array}{c}0.0883^{* * *} \\
(0.0170)\end{array}$ & $\begin{array}{c}0.1531 * * * \\
(0.0116)\end{array}$ & $\begin{array}{c}0.1324^{* * *} \\
(0.0053)\end{array}$ & $\begin{array}{c}0.1055^{* * *} \\
(0.0085)\end{array}$ & $\begin{array}{c}0.1722^{* * *} \\
(0.0084)\end{array}$ \\
\hline parcel_area $^{2}$ & $\begin{array}{c}-0.0002^{* * *} \\
(0.0000)\end{array}$ & $\begin{array}{c}-0.0003^{* * *} \\
(0.0000)\end{array}$ & $\begin{array}{c}-0.0000^{* * *} \\
(0.0000)\end{array}$ & $\begin{array}{c}-0.0008^{* * * *} \\
(0.0002)\end{array}$ & $\begin{array}{c}-0.0003^{* * *} \\
(0.0000)\end{array}$ & $\begin{array}{c}-0.0001^{* * *} \\
(0.0000)\end{array}$ & $\begin{array}{c}-0.0009 * * * \\
(0.0001)\end{array}$ \\
\hline Indistance & $\begin{array}{c}-0.2690^{* * *} \\
(0.0191)\end{array}$ & $\begin{array}{c}-0.2262^{* * *} \\
(0.0204)\end{array}$ & $\begin{array}{c}-0.2443^{* * *} \\
(0.0202)\end{array}$ & $\begin{array}{c}-0.2375^{* * * *} \\
(0.0195)\end{array}$ & $\begin{array}{c}-0.2551^{* * *} \\
(0.0111)\end{array}$ & $\begin{array}{c}-0.2226^{* * *} \\
(0.0121)\end{array}$ & $\begin{aligned}- & 0.2427^{* * * *} \\
& (0.0102)\end{aligned}$ \\
\hline$L F A R$ & $\begin{array}{c}0.0992^{* *} \\
(0.0408)\end{array}$ & $\begin{array}{c}0.0699 \\
(0.0506)\end{array}$ & $\begin{array}{c}0.0279 \\
(0.0424)\end{array}$ & $\begin{array}{c}0.0196 \\
(0.0509)\end{array}$ & $\begin{array}{c}0.0817^{* *} \\
(0.0329)\end{array}$ & $\begin{array}{c}0.1210 * * * \\
(0.0397)\end{array}$ & $\begin{array}{c}0.1425^{* * *} \\
(0.0306)\end{array}$ \\
\hline HFAR & $\begin{array}{c}0.0523 \\
(0.0425)\end{array}$ & $\begin{array}{l}0.0686^{*} \\
(0.0395)\end{array}$ & $\begin{array}{c}0.0101 \\
(0.0373)\end{array}$ & $\begin{array}{c}0.1653^{* * *} \\
(0.0364)\end{array}$ & $\begin{array}{c}0.1047^{* * *} \\
(0.0223)\end{array}$ & $\begin{array}{c}0.1425^{* * *} \\
(0.0222)\end{array}$ & $\begin{array}{c}0.1572 * * * \\
(0.0184)\end{array}$ \\
\hline Controls & yes & yes & yes & yes & yes & yes & yes \\
\hline Constant & $\begin{array}{c}8.7445^{* * *} \\
(1.4491)\end{array}$ & $\begin{array}{c}8.1323 * * * \\
(1.2764)\end{array}$ & $\begin{array}{c}8.0762 * * * \\
(1.2521)\end{array}$ & $\begin{array}{l}6.8510 * * * \\
(1.4805)\end{array}$ & $\begin{array}{c}4.6902 * * * \\
(0.7779)\end{array}$ & $\begin{array}{c}7.5395^{* * *} \\
(0.8128)\end{array}$ & $\begin{array}{c}5.9226^{* * *} \\
(0.7136)\end{array}$ \\
\hline $\mathrm{N}$ & 3480 & 3013 & 4139 & 3212 & 8143 & 9117 & 10,449 \\
\hline $\mathrm{R}^{2}$ & 0.3824 & 0.4700 & 0.4006 & 0.5229 & 0.5143 & 0.4157 & 0.5086 \\
\hline
\end{tabular}

Note: Robust standard errors in parentheses; ${ }^{* *} p<0.01,{ }^{* *} p<0.05,{ }^{*} p<0.1$. Controls are a set of control variables including parcel_resource, region, lnPGDP, industrial_structure, Intraffic, lnwage, expenditure.

According to the regression results, the estimated market coefficients are all significantly positive at the $1 \%$ level, indicating that compared with non-market-based, marketbased transfer mode can significantly increase industrial land prices and make artificially low land prices gradually approach real levels. Further, the market coefficients increased continuously from 2007 to 2009, and decreased from 2010 to 2013, which indicates that the time lag of the impact of market reform on land prices was relatively short, and could have had a large promotion effect at the early stage of the reform, while its marginal effect gradually flattened with the reform. On the whole, the effect of market reform is still very significant. The above results support Hypothesis 1 .

In terms of other variables, the results basically agree with the theoretical analysis. For example, the parcel_area coefficient is positive, while the coefficient of its quadratic term is negative, indicating that the unit price presents a downward trend with increased of land area. This is consistent with the expectation, verifying the scale effect in the transfer of land 
factor. The Indistance coefficient is significantly negative at the $1 \%$ level, indicating that the farther the land is from the city center, the lower the price will be. The LFAR coefficient is significantly positive in the later period, indicating that with the deepening of reform, the higher the lower floor area ratio, the higher the land price. The reason may be that a lower floor area ratio can restrain the subsequent land use to a certain extent. The higher the floor area ratio, the higher the land use efficiency and the higher the price. The HFAR coefficient is also significantly positive in the later period. The reason may be that compared to land without an upper floor area ratio, land with a required upper floor area ratio is usually located in key urban areas, so the price is higher. The regression results of the above indicators are consistent with the basic economic theory, indicating that when land is sold through market-based mode, the price will truly reflect the characteristic attributes of the land factor itself. This verifies the effectiveness of the market reform.

\subsection{Local Government's Strategic Choice of Land Transfer Mode against the Background of Reform}

After verifying the effect of market reform, we further subdivided the three marketbased transfer modes (tender, auction, and listing) to analyze the local government's strategic choice of transfer mode against the background of reform. According to theoretical analysis, before the reform, local governments mainly transferred industrial lands by negotiation to attract investment. After the reform, this changed to listing. If this conjecture is true, the probability will be higher that the local government's preferred enterprises will purchase land by listing (with a low market-based degree) than by auction (with a high market-based degree). Therefore, in this section, we first identify the local government's preferred enterprises, and then analyze whether there is government intervention by comparing the probability that preferred enterprises will purchase land by listing or auction.

Using a multivariate logit model, we estimated the probability of land purchase by tender, auction, and listing relative to negotiation. Tables 5 and 6 report the regression results after adding the indicators of the type and scale of the enterprise, respectively, into the model. In view of space constraints, only the first and last two years of results are reported in the text. The regression results for other years are shown in the Appendix A.

Table 5. Results of mlogit model considering types of enterprises.

\begin{tabular}{|c|c|c|c|c|c|c|}
\hline \multirow{2}{*}{ Variables } & \multicolumn{3}{|c|}{2007} & \multicolumn{3}{|c|}{2013} \\
\hline & (1) Tender & (2) Auction & (3) Listing & (4) Tender & (5) Auction & (6) Listing \\
\hline \multirow[t]{2}{*}{ state-owned enterprise } & 0.1263 & -1.1908 & -0.0251 & -15.9014 & $-1.5444^{* * *}$ & $-1.4455^{* * *}$ \\
\hline & $(0.3055)$ & $(-1.1523)$ & $(-0.1587)$ & $(-0.0114)$ & $(-5.3158)$ & $(-9.6817)$ \\
\hline \multirow[t]{2}{*}{ HKMT enterprise } & -14.7584 & -0.6408 & -0.1578 & -15.4280 & -0.1884 & -0.1990 \\
\hline & $(-0.0189)$ & $(-0.6224)$ & $(-0.7812)$ & $(-0.0080)$ & $(-0.5001)$ & $(-0.7083)$ \\
\hline \multirow[t]{2}{*}{ foreign enterprise } & -0.0004 & -0.6493 & 0.2365 & -14.7895 & 0.4711 & $0.6080 *$ \\
\hline & $(-0.0009)$ & $(-0.6277)$ & $(1.4430)$ & $(-0.0084)$ & $(1.1322)$ & $(1.8078)$ \\
\hline Controls & yes & yes & yes & yes & yes & yes \\
\hline \multirow[t]{2}{*}{ Constant } & $-18.5791 *$ & $-49.8848^{* * *}$ & $-42.4574^{* * *}$ & 7.1719 & $27.0223^{* * *}$ & $-9.5428^{* * *}$ \\
\hline & $(-1.9547)$ & $(-3.8758)$ & $(-12.5890)$ & $(0.0066)$ & $(4.9683)$ & $(-2.5882)$ \\
\hline $\mathrm{N}$ & 3480 & 3480 & 3480 & 10,449 & 10,449 & 10,449 \\
\hline Pseudo $\mathrm{R}^{2}$ & 0.0837 & 0.0837 & 0.0837 & 0.1112 & 0.1112 & 0.1112 \\
\hline
\end{tabular}

Note: Z-statistics in parentheses; ${ }^{* * *} p<0.01,{ }^{*} p<0.1$. Controls are a set of control variables including parcel_resource, region, lnPGDP, industrial_structure, Intraffic, lnwage, expenditure. Reference group of mlogit model is negotiation, dependent variable in columns 1 and 4 is the logarithmic probability of tender relative to negotiation, dependent variable in columns 2 and 5 is the logarithmic probability of auction relative to negotiation, and dependent variable in columns 3 and 6 is the logarithmic probability of listing relative to negotiation. 
Table 6. Results of mlogit model considering scale of enterprises.

\begin{tabular}{|c|c|c|c|c|c|c|}
\hline \multirow{2}{*}{ Variables } & \multicolumn{3}{|c|}{2007} & \multicolumn{3}{|c|}{2013} \\
\hline & (7) Tender & (8) Auction & (9) Listing & (10) Tender & (11) Auction & (12) Listing \\
\hline \multirow[t]{2}{*}{ large-scale enterprise } & 0.0676 & 0.3117 & 0.0543 & $-2.1653 *$ & $-0.9138^{* * *}$ & $-0.4563^{* * *}$ \\
\hline & $(0.1788)$ & $(0.5382)$ & $(0.3885)$ & $(-1.9444)$ & $(-4.2792)$ & $(-3.1774)$ \\
\hline \multirow[t]{2}{*}{ medium-scale enterprise } & -0.3627 & 0.2934 & -0.0765 & -0.1063 & -0.2150 & $-0.1964 *$ \\
\hline & $(-1.3388)$ & $(0.7519)$ & $(-0.8328)$ & $(-0.2138)$ & $(-1.3999)$ & $(-1.6923)$ \\
\hline Controls & yes & yes & yes & yes & yes & yes \\
\hline \multirow[t]{2}{*}{ Constant } & $-19.1288^{* *}$ & $-51.1120^{* * *}$ & $-42.3113^{* * *}$ & 13.3978 & $28.2626^{* * *}$ & $-8.3418 * *$ \\
\hline & $(-2.0341)$ & $(-3.9769)$ & $(-12.5907)$ & $(0.0184)$ & $(5.1914)$ & $(-2.2657)$ \\
\hline $\mathrm{N}$ & 3480 & 3480 & 3480 & 10,449 & 10,449 & 10,449 \\
\hline Pseudo $\mathrm{R}^{2}$ & 0.0817 & 0.0817 & 0.0817 & 0.1033 & 0.1033 & 0.1033 \\
\hline
\end{tabular}

Note: Z-statistics in parentheses; ${ }^{* *} p<0.01,{ }^{* *} p<0.05,{ }^{*} p<0.1$. Controls are a set of control variables including parcel_resource, region, lnPGDP, industrial_structure, Intraffic, lnwage, expenditure. Reference group of mlogit model is negotiation, dependent variable in columns 7 and 10 is the logarithmic probability of tender relative to negotiation, dependent variable in columns 8 and 11 is the logarithmic probability of auction relative to negotiation, and dependent variable in columns 9 and 12 is the logarithmic probability of listing relative to negotiation.

First, in terms of different types of enterprises, the results in Table 5 show that the HKMT enterprise and foreign enterprise coefficients are not significant, while the coefficient of state-owned enterprise by auction and listing changed from insignificant in 2007 to significantly negative in 2013. This indicates that, compared with the reference group (other mainland enterprise), there is little difference in the probability of land purchase between HKMT and foreign enterprises, while the probability of state-owned enterprises acquiring industrial land by negotiation (compared with auction and listing) is higher. Further replacing the characteristic variables of enterprises, the results in Table 6 show that in 2013, the coefficient of large-scale enterprise by auction and listing is significantly negative. Although the coefficient of medium-scale enterprise by listing only passes the significance test at $10 \%$, it is still negative, and the absolute value of the coefficient of large-scale enterprise is significantly greater than that of medium-scale enterprise, which indicates that the larger the enterprise, the higher the relative probability of land purchase by negotiation. The above results show that the type and scale of the enterprise are two important reference indices when local governments decide which enterprises they intend to transfer land to. Compared with other enterprises, governments tend to transfer industrial land to state-owned and large and medium-scale enterprises.

After determining that state-owned and large and medium-scale enterprises are preferred by governments, we further compared the relative probabilities of these enterprises to purchase land by auction and listing. It is important to note that although tender is one of the market-based transfer modes, because of its smaller sample size, ${ }^{7}$ the estimation coefficient will fluctuate greatly. Therefore, the following analysis focused on the differences between auction and listing.

The regression results show that in 2013, the coefficient of state-owned enterprise by auction was lower than that by listing (Table 5), which means that state-owned enterprises were more likely to purchase land by listing than by auction. The regression results for the scale of enterprises are also in line with expectations (Table 6). Although the significance of the coefficient of medium-scale enterprise by auction is not high, the coefficient of large-scale enterprise by auction is still smaller than that by listing, and it passes the $1 \%$ significance test. This shows that the possibility that large-scale enterprises will purchase land by listing is higher than that by auction. All in all, the above results indicate that when transferring industrial land to preferred enterprises by market-based transfer modes, local governments tend to choose listing. This provides preliminary proof of the preference of local governments for listing and supports Hypothesis 2. 


\subsection{Influence of Choice of Land Transfer Mode by Local Governments on the Price of Land Purchased by Enterprises}

The results of the previous section prove that with the advancement of industrial land market reform, local governments usually strategically choose a transfer method for the transfer of industrial land; that is, they tend to transfer land to target companies through listing. The question is, what impact will this intervention have on the results of land purchase competition among companies? Will it really reduce the land purchase cost for the intended enterprises?

Therefore, under the condition of controlling the characteristics of parcels, this section analyzes the impact of the three market-based land transfer methods on purchase prices for enterprises based on the setting of model 3. The results are shown in Table 7.

Table 7. Effects of land transfer methods on purchase prices, 2007-2013.

\begin{tabular}{|c|c|c|c|c|c|c|c|}
\hline Variables & 2007 & 2008 & 2009 & 2010 & 2011 & 2012 & 2013 \\
\hline tender & $\begin{array}{c}0.2394 \\
(0.1642)\end{array}$ & $\begin{array}{c}0.7955^{* * *} \\
(0.1406)\end{array}$ & $\begin{array}{c}0.6353^{* * *} \\
(0.1284)\end{array}$ & $\begin{array}{l}0.9608^{* * *} \\
(0.1710)\end{array}$ & $\begin{array}{c}0.8032 * * * \\
(0.2375)\end{array}$ & $\begin{array}{c}0.7440^{* * *} \\
(0.1861)\end{array}$ & $\begin{array}{c}0.6139 * * * \\
(0.1567)\end{array}$ \\
\hline auction & $\begin{array}{c}0.6815^{* * *} \\
(0.1357)\end{array}$ & $\begin{array}{c}0.6528^{* * * *} \\
(0.1398)\end{array}$ & $\begin{array}{c}0.8454^{* * *} \\
(0.0891)\end{array}$ & $\begin{array}{c}0.9867^{* * * *} \\
(0.1069)\end{array}$ & $\begin{array}{c}0.6751^{* * *} \\
(0.0749)\end{array}$ & $\begin{array}{c}0.6306^{* * *} \\
(0.0775)\end{array}$ & $\begin{array}{c}0.5350 * * * \\
(0.0652)\end{array}$ \\
\hline listing & $\begin{array}{c}0.4466^{* * * *} \\
(0.0451)\end{array}$ & $\begin{array}{c}0.6118^{* * * *} \\
(0.0612)\end{array}$ & $\begin{array}{c}0.7993^{* * *} \\
(0.0702)\end{array}$ & $\begin{array}{c}0.7095^{* * *} \\
(0.0638)\end{array}$ & $\begin{array}{c}0.6200^{* * *} \\
(0.0581)\end{array}$ & $\begin{array}{c}0.5570 * * * \\
(0.0663)\end{array}$ & $\begin{array}{c}0.5260 * * * \\
(0.0541)\end{array}$ \\
\hline parcel_area & $\begin{array}{c}0.1005^{* * * *} \\
(0.0077)\end{array}$ & $\begin{array}{c}0.1122^{* * * *} \\
(0.0098)\end{array}$ & $\begin{array}{c}0.0884^{* * * *} \\
(0.0170)\end{array}$ & $\begin{array}{c}0.1531^{* * * *} \\
(0.0116)\end{array}$ & $\begin{array}{c}0.1324^{* * *} \\
(0.0053)\end{array}$ & $\begin{array}{c}0.1055^{* * * *} \\
(0.0085)\end{array}$ & $\begin{array}{c}0.1722^{* * * *} \\
(0.0084)\end{array}$ \\
\hline parcel_area ${ }^{2}$ & $\begin{array}{c}-0.0002^{* * *} \\
(0.0000)\end{array}$ & $\begin{array}{c}-0.0003^{* * *} \\
(0.0000)\end{array}$ & $\begin{array}{c}-0.0000^{* * *} \\
(0.0000)\end{array}$ & $\begin{array}{c}-0.0008^{* * *} \\
(0.0002)\end{array}$ & $\begin{array}{c}-0.0003^{* * *} \\
(0.0000)\end{array}$ & $\begin{array}{c}-0.0001^{* * *} \\
(0.0000)\end{array}$ & $\begin{array}{c}-0.0009^{* * * *} \\
(0.0001)\end{array}$ \\
\hline Indistance & $\begin{array}{c}-0.2676^{* * *} \\
(0.0191)\end{array}$ & $\begin{array}{c}-0.2265^{* * *} \\
(0.0204)\end{array}$ & $\begin{array}{c}-0.2444^{* * *} \\
(0.0202)\end{array}$ & $\begin{array}{c}-0.2378^{* * *} \\
(0.0195)\end{array}$ & $\begin{array}{c}-0.2556^{* * *} \\
(0.0111)\end{array}$ & $\begin{array}{c}-0.2228^{* * *} \\
(0.0121)\end{array}$ & $\begin{array}{c}-0.2428^{* * *} \\
(0.0102)\end{array}$ \\
\hline$L F A R$ & $\begin{array}{l}0.0948 * * \\
(0.0409)\end{array}$ & $\begin{array}{c}0.0720 \\
(0.0505)\end{array}$ & $\begin{array}{c}0.0268 \\
(0.0424)\end{array}$ & $\begin{array}{c}0.0138 \\
(0.0512)\end{array}$ & $\begin{array}{c}0.0807 * * \\
(0.0329)\end{array}$ & $\begin{array}{c}0.1202 * * * \\
(0.0397)\end{array}$ & $\begin{array}{c}0.1425 * * * \\
(0.0307)\end{array}$ \\
\hline HFAR & $\begin{array}{c}0.0496 \\
(0.0424)\end{array}$ & $\begin{array}{l}0.0692 * \\
(0.0396)\end{array}$ & $\begin{array}{c}0.0114 \\
(0.0371)\end{array}$ & $\begin{array}{c}0.1638^{* * *} \\
(0.0364)\end{array}$ & $\begin{array}{c}0.1044^{* * *} \\
(0.0223)\end{array}$ & $\begin{array}{c}0.1421^{* * *} \\
(0.0222)\end{array}$ & $\begin{array}{c}0.1573 * * * \\
(0.0184)\end{array}$ \\
\hline Controls & Yes & Yes & Yes & Yes & Yes & Yes & Yes \\
\hline Constant & $\begin{array}{c}8.8577^{* * *} \\
(1.4555)\end{array}$ & $\begin{array}{c}8.2356^{* * *} \\
(1.2823)\end{array}$ & $\begin{array}{c}8.0307^{* * *} \\
(1.2547)\end{array}$ & $\begin{array}{c}6.9071^{* * *} \\
(1.4834)\end{array}$ & $\begin{array}{c}4.6680^{* * * *} \\
(0.7789)\end{array}$ & $\begin{array}{c}7.4021^{* * * *} \\
(0.8203)\end{array}$ & $\begin{array}{c}5.9048^{* * *} \\
(0.7161)\end{array}$ \\
\hline $\mathrm{N}$ & 3480 & 3013 & 4139 & 3212 & 8143 & 9117 & 10,449 \\
\hline $\mathrm{R}^{2}$ & 0.3831 & 0.4705 & 0.4010 & 0.5245 & 0.5144 & 0.4159 & 0.5087 \\
\hline
\end{tabular}

Note: Robust standard errors in parentheses; ${ }^{* * *} p<0.01,{ }^{* *} p<0.05,{ }^{*} p<0.1$. Controls are a set of control variables including parcel_resource, region, $\ln P G D P$, industrial_structure, Intraffic, lnwage, expenditure.

The regression results in Table 7 show that from 2007 to 2013, the auction coefficient is greater than the listing coefficient, indicating that compared to auction, which represents a higher degree of marketization, listing has a weaker effect on increasing industrial land transfer prices. This also illustrates that the price of land purchased by enterprises through listing is relatively low, and implies that local governments supply land to target enterprises at a low price, which means an implicit land subsidy exists.

According to the previous analysis, local governments often judge target enterprises based on the type of ownership and the scale of the enterprise. In order to further test the effect of implicit land price subsidy in the context of market-oriented reform, this paper incorporates the enterprise type and scale indicators into the marginal analysis.

Figure 3 reports the average marginal effect of the cross-products of the types of enterprise ownership and the transfer modes on land purchase prices in 2007 and 2013 when other variables are at the average level. In order to make the results more intuitive, we divided the types of enterprise ownership into two groups: state-owned and non-stateowned. By comparing the first and last two years, it can be seen that in 2007 the marginal purchase price of land was higher for state-owned than non-state-owned enterprises, but in 2013 it was the opposite. It was found that compared with non-state-owned enterprises, the marginal purchase price of land for state-owned enterprises through listing was lower, 
which confirms the existence of price subsidies. At the same time, it can also be seen that the price gap between negotiation and listing was constantly narrowing.
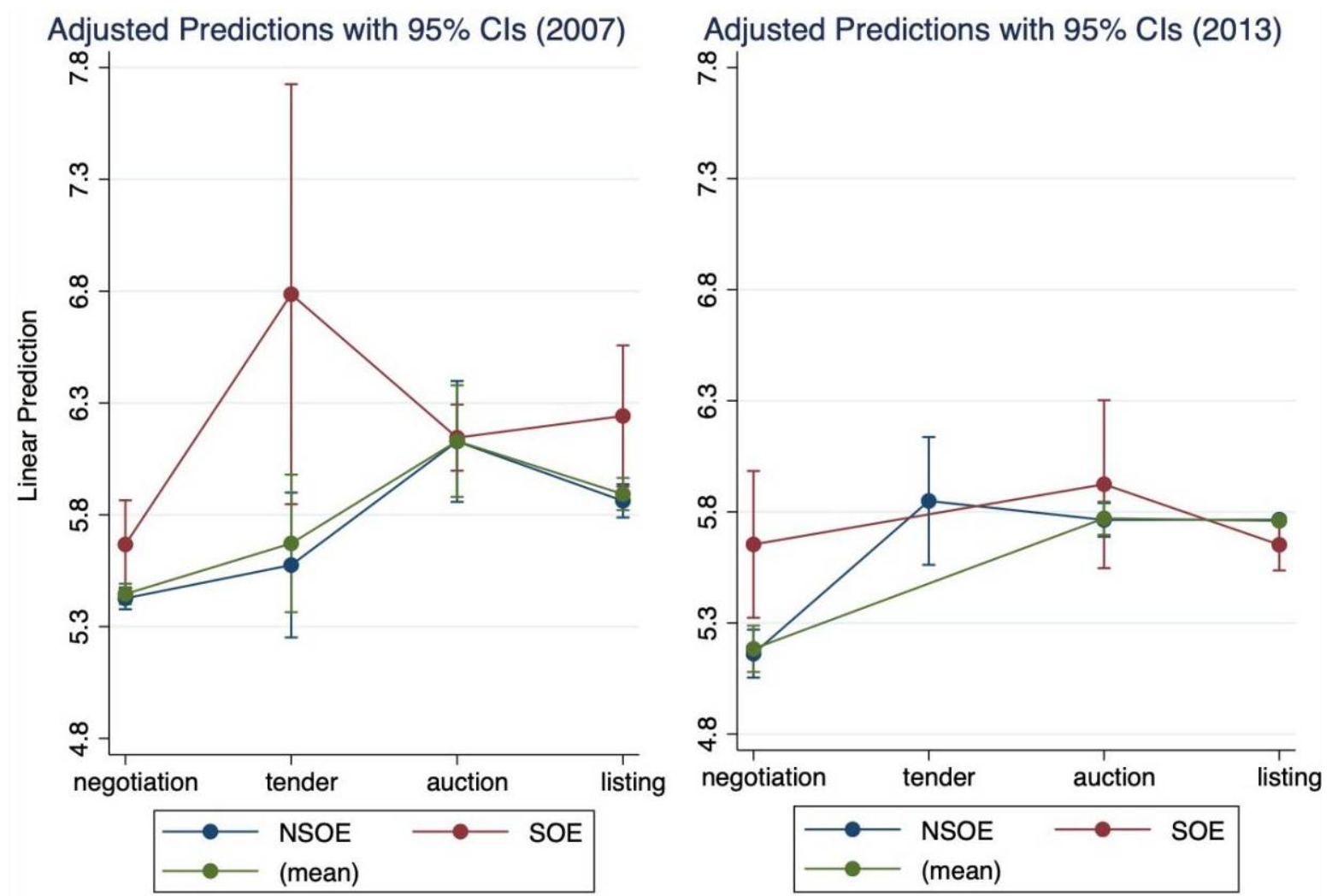

Figure 3. Average marginal effect of cross-products of types of enterprise ownership and transfer modes on land purchase prices in 2007 and 2013. SOE, state-owned enterprise; NSOE, non-state-owned enterprise. Sample size of industrial land transferred through bidding is too small, which makes it impossible to estimate the average marginal effect of state-owned enterprises under this transfer method, but this does not affect the analysis results of the other transfer methods. Only samples of negotiation, auction, and listing are included in this paper, and the results are consistent here.

The above findings indicate that at the beginning of the industrial land market reform, state-owned enterprises obtained more land price subsidies through negotiation to purchase land. However, with the advancement of the reform, China gradually increased land transfer control, and state-owned enterprises gradually lost the advantage of purchasing land through negotiation. When it is difficult for local governments to provide land at low prices through negotiation, listing becomes an alternative intervention tool. The government can provide state-owned enterprises with land price subsidies through listing. The above analysis of the types of enterprises confirms part of Hypothesis 3.

Figure 4 reports the average marginal effect of the cross-products of enterprise scales and transfer modes on land purchase prices in 2007 and 2013. At the beginning of the reform in 2007, although the marginal land purchase prices for enterprises with different scales were different, the overall ranking and curve trend were very consistent, indicating that the marginal price is affected by the scale of the company. However, in 2013, the trend of the curve clearly differed according to company size and transfer modes. The marginal land prices of large and medium-sized enterprises for listing were still lower than those for auction, while the marginal value of small enterprises for listing was higher than that for auction, indicating that when companies of different scales purchase land by different transfer modes, the marginal land price trends are also different. 

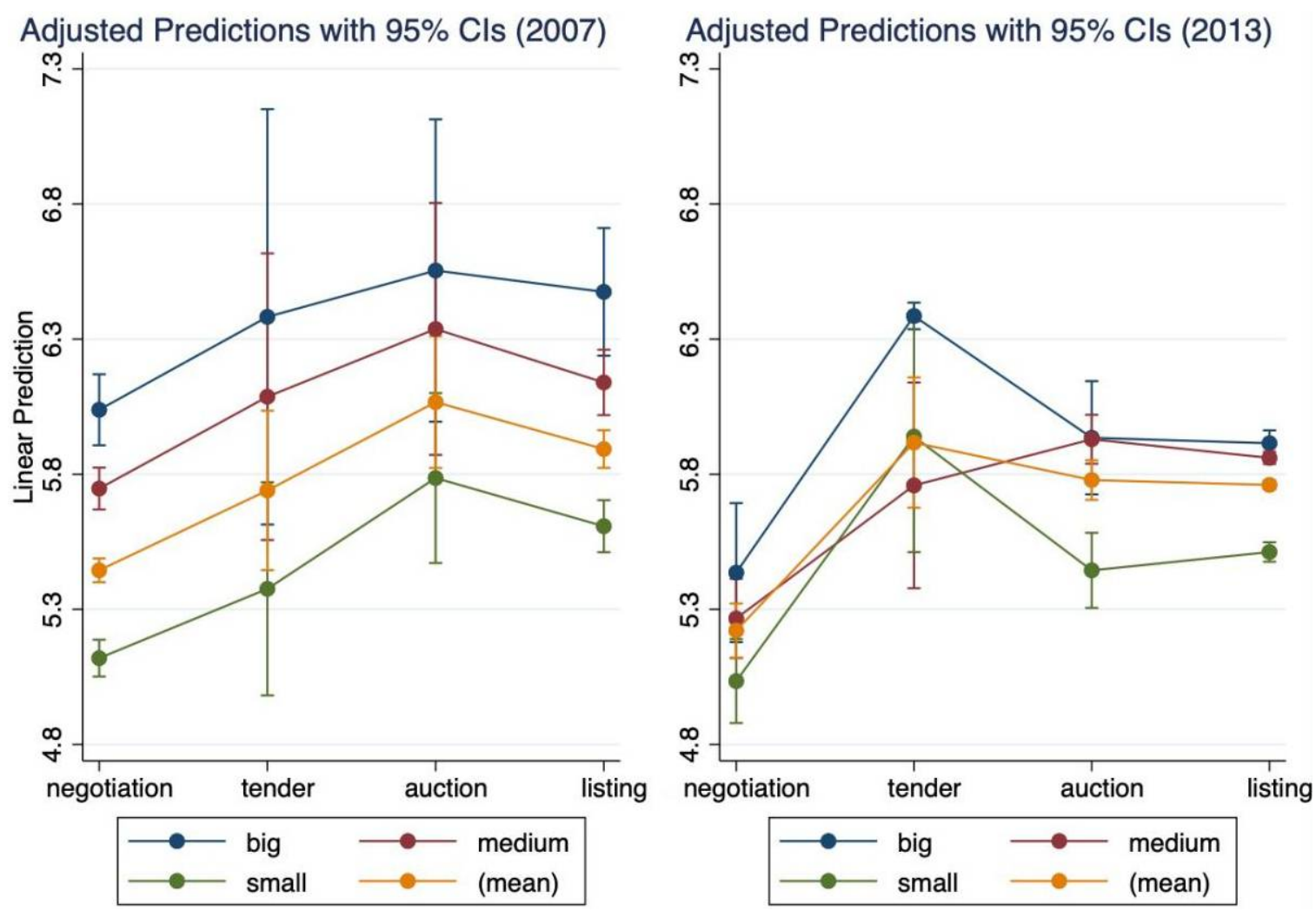

Figure 4. Average marginal effect of cross-products of enterprise scales and transfer modes on land purchase prices in 2007 and 2013.

It can be seen that in the context of market-oriented transfers of industrial land, enterprises of different sizes can enjoy different levels of land price subsidies. The larger the scale of the enterprise, the higher the subsidy level. The above analysis on the size of the enterprise further proves Hypothesis 3. However, it should be noted that under the same transfer mode, the purchase prices for large and medium-sized enterprises are generally higher than those for small enterprises, which is inconsistent with the expectation that the former should receive more land subsidies. This paper posits that the reason may be related to the company's capital stock. Specific explanations are given below.

\subsection{Influence of Choice of Land Transfer Mode by Local Governments on Enterprises' Willingness to Bid}

It has been found that local governments usually make strategic choices when conducting market-oriented transfers of industrial land. By providing land price subsidies to target companies through listing, local governments can reduce corporate investment costs and attract companies to build factories. For enterprises, the land price, as the cost of investment, is the first indicator measuring their decision to compete for land. However, it may be problematic to judge competitive advantage based on the bid level alone, because larger companies often offer higher bids than companies with fewer assets, due to smaller capital constraints. However, this does not mean that companies with less capital receive more land subsidies. In order to make the results more robust and more in line with reality, we further constructed corporate bidding indicators under capital constraints.

The willingness to bid indicator (Inwillingness) was constructed by using the ratio of the enterprise's total land purchase price to its current assets, replacing the land price as the explained variable to examine the price that the enterprise is willing to pay under the condition of capital constraints. Similarly, transfer modes, types of enterprise ownership, and enterprise scales were added to the model to test the influence of the government's strategic choices on enterprises' willingness to bid. The enterprise scale indicator was 
measured by the total amount of corporate assets described above. Here, because the explanatory variable adopts current assets, and total assets are positively correlated with current assets, in order to avoid an endogeneity problem, in this section we replace the enterprise scale index with the logarithm of the number of employees (Inscale).

The regression results are listed in Table 8. In view of space constraints, only the first and last two years of results are reported in the text. Regression results for other years are shown in the Appendix A. Columns 1 and 3 show the results considering the types of enterprise ownership, and columns 2 and 4 show the results considering the scale of the company. The results show that the estimated coefficients of auction and listing were significantly positive in both 2007 and 2013, and although the estimated coefficient of tender was not significant in 2007, it was significantly positive in 2013. This shows that when considering capital constraints, compared with negotiation, the market-based transfer modes raise land purchase prices. This result further verifies Hypothesis 1 . In addition, the estimated coefficients of auction in 2007 and 2013 are higher than those of listing, which means that compared with auction, the willingness to bid through listing is weaker, that is, companies tend to purchase land at low prices. The above findings are consistent with the previous case with land price as the explained variable, indicating that local governments can indeed supply companies with low-price land through listing.

Table 8. Influence of industrial land transfer modes on enterprises' willingness to bid.

\begin{tabular}{|c|c|c|c|c|}
\hline \multirow{2}{*}{ Variables } & \multicolumn{2}{|c|}{2007} & \multicolumn{2}{|c|}{2013} \\
\hline & (1) & (2) & (3) & (4) \\
\hline tender & $\begin{array}{c}0.1090 \\
(0.2118)\end{array}$ & $\begin{array}{c}0.1034 \\
(0.1927)\end{array}$ & $\begin{array}{c}1.0439 * * * \\
(0.3468)\end{array}$ & $\begin{array}{c}0.9945^{* * *} \\
(0.3362)\end{array}$ \\
\hline auction & $\begin{array}{l}0.4057^{*} \\
(0.2401)\end{array}$ & $\begin{array}{l}0.4808^{* *} \\
(0.2250)\end{array}$ & $\begin{array}{c}0.8090 * * * \\
(0.1097)\end{array}$ & $\begin{array}{c}0.7912 * * * \\
(0.1036)\end{array}$ \\
\hline listing & $\begin{array}{c}0.3702^{* * *} \\
(0.0665)\end{array}$ & $\begin{array}{c}0.3539 * * * \\
(0.0592)\end{array}$ & $\begin{array}{c}0.6175^{* * *} \\
(0.0836)\end{array}$ & $\begin{array}{c}0.6499 * * * \\
(0.0788)\end{array}$ \\
\hline state-owned enterprise & $\begin{array}{c}-1.7965^{* * *} \\
(0.1325)\end{array}$ & & $\begin{array}{c}-1.4826^{* * *} \\
(0.0961)\end{array}$ & \\
\hline HKMT enterprise & $\begin{array}{c}-0.5060^{* * *} \\
(0.1176)\end{array}$ & & $\begin{array}{c}-0.5019^{* * *} \\
(0.0972)\end{array}$ & \\
\hline foreign enterprise & $\begin{array}{c}-0.5426^{* * *} \\
(0.1064)\end{array}$ & & $\begin{array}{c}-0.6051^{* * *} \\
(0.0886)\end{array}$ & \\
\hline Inscale & & $\begin{array}{c}-0.6812 * * * \\
(0.0245)\end{array}$ & & $\begin{aligned}- & 0.5820 * * * \\
& (0.0194)\end{aligned}$ \\
\hline parcel_area & $\begin{array}{c}0.0080 \\
(0.0051)\end{array}$ & $\begin{array}{l}0.0207 * * \\
(0.0089)\end{array}$ & $\begin{array}{c}0.0338^{* * *} \\
(0.0051)\end{array}$ & $\begin{array}{c}0.0345^{* * *} \\
(0.0050)\end{array}$ \\
\hline Indistance & $\begin{array}{c}-0.1051^{* * *} \\
(0.0289)\end{array}$ & $\begin{array}{c}-0.1045^{* * *} \\
(0.0254)\end{array}$ & $\begin{array}{c}-0.0763^{* * *} \\
(0.0173)\end{array}$ & $\begin{aligned}- & 0.0815^{* * * *} \\
& (0.0167)\end{aligned}$ \\
\hline LFAR & $\begin{array}{l}0.0978^{*} \\
(0.0591)\end{array}$ & $\begin{array}{c}0.1430^{* * * *} \\
(0.0534)\end{array}$ & $\begin{array}{c}0.1495^{* * *} \\
(0.0525)\end{array}$ & $\begin{array}{c}0.1867^{* * *} \\
(0.0510)\end{array}$ \\
\hline HFAR & $\begin{array}{l}-0.0800 \\
(0.0609)\end{array}$ & $\begin{array}{l}-0.0526 \\
(0.0547)\end{array}$ & $\begin{array}{c}0.1393^{* * *} \\
(0.0327)\end{array}$ & $\begin{array}{c}0.1295^{* * *} \\
(0.0314)\end{array}$ \\
\hline Controls & Yes & Yes & Yes & Yes \\
\hline Constant & $\begin{array}{c}9.7951^{* * *} \\
(2.1328)\end{array}$ & $\begin{array}{c}19.7400 * * * \\
(1.9361)\end{array}$ & $\begin{array}{c}13.0959^{* * *} \\
(1.1872)\end{array}$ & $\begin{array}{c}17.9936^{* * *} \\
(1.1434)\end{array}$ \\
\hline $\mathrm{N}$ & 3480 & 3480 & 10,449 & 10,449 \\
\hline$R^{2}$ & 0.1255 & 0.3009 & 0.0938 & 0.1624 \\
\hline
\end{tabular}

Note: Robust standard errors in parentheses; ${ }^{* * *} p<0.01,{ }^{* *} p<0.05,{ }^{*} p<0.1$. Controls are a set of control variables including parcel_resource, region, lnPGDP, industrial_structure, Intraffic, lnwage, expenditure.

In order to further examine different enterprises' willingness to bid, this paper takes the types of enterprise ownership and the scale of the enterprise as the core explanatory variables, and then performs group regression on the two subsamples of negotiation and listing. The results are shown in Tables 9 and 10, where columns 1 and 3 show the regression 
results after adding the enterprise ownership type index, and columns 2 and 4 show the regression results after including the enterprise scale index.

Table 9. Results of enterprises' willingness to bid when industrial land is transferred through negotiation.

\begin{tabular}{ccccc}
\hline \multirow{2}{*}{ Variables } & \multicolumn{2}{c}{2007} & $\mathbf{2} 2013$ \\
\cline { 2 - 5 } & $\mathbf{( 1 )}$ & $\mathbf{( 2 )}$ & $\mathbf{( 3 )}$ & $\mathbf{( 4 )}$ \\
\hline state-owned enterprise & $-1.7672^{* * *}$ & & $-0.9425^{* * *}$ \\
& $(0.1543)$ & & $(0.2762)$ \\
HKMT enterprise & $-0.5030^{* * *}$ & -0.4420 \\
foreign enterprise & $(0.1244)$ & $-0.4652)$ \\
& $-0.5848^{* * *}$ & $-1.3477^{*}$ & \\
Inscale & $(0.1286)$ & $-0.7091^{* * *}$ & $(0.8036)$ & $-0.7165^{* * *}$ \\
& \multicolumn{4}{c}{$(0.0851)$} \\
Controls & Yes & Yes & Yes & Yes \\
Constant & $9.2319^{* * *}$ & $20.4373^{* * *}$ & $17.7252^{* * * *}$ & $17.1323^{* * *}$ \\
& $(2.5625)$ & $(2.2782)$ & $(6.4035)$ & $(5.8112)$ \\
$\mathrm{N}$ & 2531 & 2531 & 505 & 505 \\
$\mathrm{R}^{2}$ & 0.1177 & 0.3120 & 0.1288 & 0.2196 \\
\hline
\end{tabular}

Note: Robust standard errors in parentheses; ${ }^{* * *} p<0.01,{ }^{*} p<0.1$. Controls are a set of control variables including parcel_area, Indistance, LFAR, HFAR, parcel_resource, region, lnPGDP, industrial_structure, Intraffic, lnwage, expenditure.

Table 10. Results of enterprises' willingness to bid when industrial land is transferred through listing.

\begin{tabular}{|c|c|c|c|c|}
\hline \multirow{2}{*}{ Variables } & \multicolumn{2}{|c|}{2007} & \multicolumn{2}{|c|}{2013} \\
\hline & (1) & (2) & (3) & (4) \\
\hline state-owned enterprise & $\begin{array}{c}-1.8310 * * * \\
(0.2509)\end{array}$ & & $\begin{array}{c}-1.5624^{* * *} \\
(0.1053)\end{array}$ & \\
\hline HKMT enterprise & $\begin{array}{l}-0.5174 \\
(0.3414)\end{array}$ & & $\begin{array}{c}-0.5577^{* * *} \\
(0.1024)\end{array}$ & \\
\hline foreign enterprise & $\begin{array}{l}-0.2964 \\
(0.1896)\end{array}$ & & $\begin{array}{c}-0.6065^{* * *} \\
(0.0904)\end{array}$ & \\
\hline Inscale & & $\begin{array}{c}-0.6725^{* * *} \\
(0.0425)\end{array}$ & & $\begin{array}{c}-0.5738^{* * *} \\
(0.0206)\end{array}$ \\
\hline Controls & Yes & Yes & Yes & Yes \\
\hline Constant & $\begin{array}{l}6.9359 * \\
(4.2049)\end{array}$ & $\begin{array}{c}14.8513^{* * *} \\
(3.7321)\end{array}$ & $\begin{array}{c}13.3863^{* * *} \\
(1.2369)\end{array}$ & $\begin{array}{c}18.0797^{* * *} \\
(1.1914)\end{array}$ \\
\hline $\mathrm{N}$ & 841 & 841 & 9430 & 9430 \\
\hline$R^{2}$ & 0.1576 & 0.3196 & 0.0869 & 0.1521 \\
\hline
\end{tabular}

Note: Robust standard errors in parentheses; ${ }^{* * *} p<0.01,{ }^{*} p<0.1$. Controls are a set of control variables including parcel_area, Indistance, LFAR, HFAR, parcel_resource, region, lnPGDP, industrial_structure, Intraffic, lnwage, expenditure.

With regard to the types of enterprise ownership, the regression coefficients of stateowned enterprises are significantly negative, and the absolute values of the coefficients are relatively large (Tables 9 and 10). This also shows that compared with non-stateowned enterprises, even if financial constraints are considered, state-owned enterprises still purchase land at lower prices, and can obtain land subsidies through negotiation and listing. In contrast, in 2007, the coefficients of state-owned enterprise negotiation and listing are both significantly negative. However, in 2013, the coefficients of state-owned enterprises under negotiation are still negative, but the absolute values are lower than those of foreign enterprises, and the coefficients of state-owned enterprises under listing are not only significantly negative, but also higher in absolute value than other non-state-owned enterprises. It can be seen that with the continuous advancement of reforms, the way that state-owned enterprises have obtained land price subsidies has shifted from negotiation to listing. 
With regard to enterprise scale, the coefficients of Inscale are all significantly negative, indicating that the larger the scale, the lower the purchase price of land. This also explains why the land purchase prices for large and medium-sized enterprises described above are generally higher than those of small enterprises. That is to say, the high land prices paid by large and medium-sized enterprises are mainly due to the large scale and assets of these enterprises. With capital constraints under control, large-scale enterprises can enjoy more land price subsidies, so their land purchase prices are also lower. The above results further verify Hypothesis 3.

\section{Robustness Check}

The above regression results on enterprises' willingness to bid can be regarded as a robustness test of the land purchase price as the explained variable. Next, this paper focuses on testing the robustness of the results of the multinomial logit model.

\subsection{Indifference Test between Groups}

By using multinomial logit model, we estimated the selection probabilities of the three kinds of market-based transfer modes relative to the agreement transfer. When using this model, it is necessary to test whether the explanatory variables have a significant influence on the odds ratio among the four transfer modes of tender, auction, listing, and negotiation, to ensure that the method of dividing them is reasonable. This section uses the LR test to achieve this aim. If the result rejects the null hypothesis, it indicates that the above classification method is appropriate. The results are shown in the Tables 11 and 12. According to the results, each combination passed the indifference test between groups, which proves that the model 1 grouping is reasonable. Due to space limitations, only the results of 2007 and 2013 are reported here.

Table 11. Indifference test between groups, 2007.

\begin{tabular}{ccccccc}
\hline \multirow{2}{*}{ Groups } & \multicolumn{2}{c}{ Types of Enterprise Ownership } & \multicolumn{3}{c}{ Enterprise Scale } \\
\cline { 2 - 7 } & Chi2 & df & $p>$ Chi2 & Chi2 & df & $p>$ Chi2 \\
\hline Negotiation-tender & 55.2590 & 12.0000 & 0.0000 & 49.2440 & 11.0000 & 0.0000 \\
Negotiation-auction & 47.8090 & 12.0000 & 0.0000 & 45.9090 & 11.0000 & 0.0000 \\
Negotiation-listing & 326.0320 & 12.0000 & 0.0000 & 324.5770 & 11.0000 & 0.0000 \\
Tender-auction & 26.3910 & 12.0000 & 0.0090 & 23.7570 & 11.0000 & 0.0140 \\
Tender-listing & 35.4660 & 12.0000 & 0.0000 & 29.6810 & 11.0000 & 0.0020 \\
Auction-listing & 30.9810 & 12.0000 & 0.0020 & 29.1280 & 11.0000 & 0.0020 \\
\hline
\end{tabular}

Table 12. Indifference test between groups, 2013.

\begin{tabular}{ccccccc}
\hline \multirow{2}{*}{ Groups } & \multicolumn{2}{c}{ Types of Enterprise Ownership } & \multicolumn{3}{c}{ Enterprise Scale } \\
\cline { 2 - 6 } & Chi2 & df & $p>$ Chi2 & Chi2 & df & $p>$ Chi2 \\
\hline Negotiation-tender & 75.7300 & 12.0000 & 0.0000 & 73.8960 & 11.0000 & 0.0000 \\
Negotiation-auction & 492.3540 & 12.0000 & 0.0000 & 476.9740 & 11.0000 & 0.0000 \\
Negotiation-listing & 531.1030 & 12.0000 & 0.0000 & 458.1690 & 11.0000 & 0.0000 \\
Tender-auction & 36.5090 & 12.0000 & 0.0000 & 33.0200 & 11.0000 & 0.0010 \\
Tender-listing & 53.9960 & 12.0000 & 0.0000 & 52.2470 & 11.0000 & 0.0000 \\
Auction-listing & 329.5390 & 12.0000 & 0.0000 & 338.2280 & 11.0000 & 0.0000 \\
\hline
\end{tabular}

\subsection{Test for Independence of Irrelevant Alternatives}

When using the multinomial logit model, it is necessary to satisfy the assumption of independence of irrelevant alternatives (IIA), that is, the estimated odds ratio is independent of the influence of other choices. Tables 13 and 14 report the results of the Hausman test for model 1 in 2007 and 2013. According to the test results, the four choices of model 1 all accept the null hypothesis and pass the Hausman test, which proves that increasing or 
reducing the number of choices has no effect on the probability of existing choices. The setting of model 1 is reasonable.

Table 13. IIA test results, 2007.

\begin{tabular}{|c|c|c|c|c|c|c|}
\hline \multirow{2}{*}{ Groups } & \multicolumn{3}{|c|}{ Types of Enterprise Ownership } & \multicolumn{3}{|c|}{ Enterprise Scale } \\
\hline & Chi2 & df & $p>$ Chi2 & Chi2 & df & $p>$ Chi2 \\
\hline Negotiation & -1.3500 & 18.0000 & & -0.9480 & 24.0000 & . \\
\hline Tender & 2.6910 & 25.0000 & 1.0000 & 1.3770 & 23.0000 & 1.0000 \\
\hline Auction & -0.1020 & 4.0000 & . & -0.1930 & 23.0000 & \\
\hline Listing & -2.2510 & 14.0000 & . & 7.6090 & 23.0000 & 0.9990 \\
\hline
\end{tabular}

Table 14. IIA test results, 2013.

\begin{tabular}{ccccccc}
\hline \multirow{2}{*}{ Groups } & \multicolumn{2}{c}{ Types of Enterprise Ownership } & \multicolumn{4}{c}{ Enterprise Scale } \\
\cline { 2 - 7 } & Chi2 & $\mathbf{d f}$ & $\boldsymbol{p}>$ Chi2 & Chi2 & df & $\boldsymbol{p}>$ Chi2 \\
\hline Negotiation & 0.2700 & 8.0000 & 1.0000 & 1.7780 & 8.0000 & 0.9870 \\
Tender & -1.0900 & 25.0000 &. & 1.0270 & 22.0000 & 1.0000 \\
Auction & 5.9180 & 8.0000 & 0.6560 & -5.7350 & 8.0000 &. \\
Listing & 8.1920 & 11.0000 & 0.6960 & 1.6550 & 13.0000 & 1.0000 \\
\hline
\end{tabular}

\subsection{Results of Logit Regression}

In addition to the above two tests, this paper uses the logit model in addition to the multinomial logit model to estimate the selection probability of auction and listing relative to negotiation, as shown in Tables 15 and 16. It can be seen that the regression results of the logit and multinomial logit models are basically the same, which proves that the results of the latter are relatively robust.

Table 15. Regression results of logit model for auction.

\begin{tabular}{|c|c|c|c|c|c|c|c|c|}
\hline \multirow{2}{*}{ Variables } & \multicolumn{4}{|c|}{2007} & \multicolumn{4}{|c|}{2013} \\
\hline & (1) Mlogit & (2) Logit & (3) Mlogit & (4) Logit & (5) Mlogit & (6) Logit & (7) Mlogit & (8) Logit \\
\hline state-owned & -1.1908 & -1.2165 & & & $-1.5444^{* * *}$ & $-1.5350 * * *$ & & \\
\hline enterprise & $(-1.1523)$ & $(-1.1696)$ & & & $(-5.3158)$ & $(-4.7016)$ & & \\
\hline HKMT & -0.6408 & -0.6646 & & & -0.1884 & 0.0903 & & \\
\hline enterprise & $(-0.6224)$ & $(-0.6427)$ & & & $(-0.5001)$ & $(0.2015)$ & & \\
\hline foreign & -0.6493 & -0.6762 & & & 0.4711 & 0.2528 & & \\
\hline enterprise & $(-0.6277)$ & $(-0.6499)$ & & & (1.1322) & $(0.5415)$ & & \\
\hline \multirow[t]{2}{*}{ large-scale } & & & 0.3117 & 0.2862 & & & $-0.9138^{* * *}$ & $-0.8189 * * *$ \\
\hline & & & $(0.5382)$ & $(0.4912)$ & & & $(-4.2792)$ & $(-3.2630)$ \\
\hline \multirow[t]{2}{*}{ medium-scale } & & & 0.2934 & 0.2652 & & & -0.2150 & -0.2772 \\
\hline & & & $(0.7519)$ & $(0.6738)$ & & & $(-1.3999)$ & $(-1.4905)$ \\
\hline Controls & Yes & Yes & Yes & Yes & Yes & Yes & Yes & Yes \\
\hline Constant & $\begin{array}{c}-49.8848^{* * *} \\
(-3.8758)\end{array}$ & $\begin{array}{c}-48.6596 \text { *** } \\
(-3.6756)\end{array}$ & $\begin{array}{c}-51.1120 * * * \\
(-3.9769)\end{array}$ & $\begin{array}{c}-48.7134 \text { *** } \\
(-3.7074)\end{array}$ & $\begin{array}{c}27.0223 * * * \\
(4.9683)\end{array}$ & $\begin{array}{c}27.0485^{* * *} \\
(3.5824)\end{array}$ & $\begin{array}{c}28.2626^{* * *} \\
(5.1914)\end{array}$ & $\begin{array}{c}26.5533 * * * \\
(3.5934)\end{array}$ \\
\hline $\mathrm{N}$ & 3480 & 2563 & 3480 & 2563 & 10,449 & 997 & 10,449 & 997 \\
\hline Pseudo $\mathrm{R}^{2}$ & 0.0837 & 0.1350 & 0.0817 & 0.1286 & 0.1112 & 0.3166 & 0.1033 & 0.3059 \\
\hline
\end{tabular}

Note: Z-statistics in parentheses; ${ }^{* *} p<0.01$. Controls are a set of control variables including parcel_resource, region, lnPGDP, industrial_structure, Intraffic, lnwage, expenditure. Reference group of model is negotiation, and the regression results in columns $1,2,5$, and 6 consider the type of enterprise; regression results in columns 3,4,7, and 8 consider the scale of enterprises. 
Table 16. Regression results of logit model for listing.

\begin{tabular}{|c|c|c|c|c|c|c|c|c|}
\hline \multirow{2}{*}{ Variables } & \multicolumn{4}{|c|}{2007} & \multicolumn{4}{|c|}{2013} \\
\hline & (1) Mlogit & (2) Logit & (3) Mlogit & (4) Logit & (5) Mlogit & (6) Logit & (7) Mlogit & (8) Logit \\
\hline state-owned & -0.0251 & -0.0141 & & & $-1.4455^{* * *}$ & $-1.4446^{* * *}$ & & \\
\hline enterprise & $(-0.1587)$ & $(-0.0892)$ & & & $(-9.6817)$ & $(-9.6451)$ & & \\
\hline HKMT & -0.1578 & -0.1540 & & & -0.1990 & -0.1867 & & \\
\hline enterprise & $(-0.7812)$ & $(-0.7616)$ & & & $(-0.7083)$ & $(-0.6641)$ & & \\
\hline \multirow{2}{*}{$\begin{array}{c}\text { foreign } \\
\text { enterprise }\end{array}$} & 0.2365 & 0.2517 & & & 0.6080 * & 0.6216 * & & \\
\hline & $(1.4430)$ & (1.5345) & & & (1.8078) & $(1.8476)$ & & \\
\hline \multirow[t]{2}{*}{ large-scale } & & & 0.0543 & 0.0637 & & & $-0.4563^{* * *}$ & $-0.4508^{* * *}$ \\
\hline & & & $(0.3885)$ & $(0.4562)$ & & & $(-3.1774)$ & $(-3.1335)$ \\
\hline \multirow[t]{2}{*}{ medium-scale } & & & -0.0765 & -0.0763 & & & -0.1964 * & $-0.1917^{*}$ \\
\hline & & & $(-0.8328)$ & $(-0.8287)$ & & & $(-1.6923)$ & $(-1.6505)$ \\
\hline Controls & Yes & Yes & Yes & Yes & Yes & Yes & Yes & Yes \\
\hline \multirow[t]{2}{*}{ Constant } & $-42.4574^{* * *}$ & $-42.8774^{* * *}$ & $-42.3113^{* * *}$ & $-42.6663^{* * *}$ & $-9.5428^{* * *}$ & $-9.3563^{* *}$ & -8.3418 ** & $-8.0117^{* *}$ \\
\hline & $(-12.5890)$ & $(-12.6544)$ & $(-12.5907)$ & $(-12.6394)$ & $(-2.5882)$ & $(-2.5417)$ & $(-2.2657)$ & $(-2.1829)$ \\
\hline $\mathrm{N}$ & 3480 & 3372 & 3480 & 3372 & 10,449 & 9935 & 10,449 & 9935 \\
\hline Pseudo $\mathrm{R}^{2}$ & 0.0837 & 0.0867 & 0.0817 & 0.0862 & 0.1112 & 0.1320 & 0.1033 & 0.1138 \\
\hline
\end{tabular}

Note: Z-statistics in parentheses; ${ }^{* *} p<0.01,{ }^{* *} p<0.05,{ }^{*} p<0.1$. Controls are a set of control variables including parcel_resource, region, lnPGDP, industrial_structure, lntraffic, lnwage, expenditure. Reference group of model is negotiation, and regression results in columns 1 , 2,5 , and 6 consider the type of enterprise; regression results in columns 3, 4, 7, and 8 consider the scale of enterprises.

\section{Discussion}

Based on the micro-level land transaction database, this paper discusses the local government's strategic choice of land transfer mode and the implicit land price subsidy reflected in the background of the market-oriented reform of industrial land.

Besides the above research conclusions, the future research prospects can be summarized as follows:

In terms of motivation, regarding local governments' land price subsidies for industrial land, most studies suggest that they distort land prices and affect the effective allocation of resources, which is unreasonable. However, some studies suggest that in exchange for long-term economic development of the region with short-term land benefits, from a long-term perspective, it is beneficial for regional economic development. To a certain extent, land price subsidies can attract a large amount of investment, especially the inflow of foreign capital, and then promote the construction of parks and the export-oriented development of the regional economy [38]. In reality, there are successful cases: Suzhou Industrial Park, Fuzhou Minhou Qingkou Automobile City, etc., all of which have played a huge role in driving the economic development of the region.

According to the research in this paper, in the context of marketization, local governments still tend to provide implicit land price subsidies to target companies, but the degree has been restricted to a small range, and price distortions are also limited. Basically, it reflects the overall trend of the market determining prices. So, what long-term effects will such subsidies have on industrial development and economic growth in the region? In exchange for short-term land price gains for long-term industrial investment, do the advantages outweigh the disadvantages, or vice versa? This needs to be further explored in further research.

Regarding the time update of the sample data, the land data (2007-2019) used in this paper came from China Land Market Net, which was compiled by the author. After the market-oriented reform of industrial land, it was required that all industrial land transfer information be published on the website, so only industrial land transfer data from 2007 and later can be obtained. Regarding enterprise data, this paper selected the China Industrial Enterprise Database, which covers the period 2003-2013. This database is commonly used for studying Chinese economic issues and contains a large amount of data and a relatively comprehensive sample. Next, the above two databases were manually matched by company name to obtain the final industrial enterprise land purchase database, and the research was extended to the micro-enterprise level. The workload of data matching in this 
paper was very large, and because the time periods of the two databases are different, in the final matching results some years were discarded, and we obtained a database from 2007 to 2013. From the perspective of research design, including the consideration of policy lag effects, this time series met the research purpose without affecting the scientific nature of the conclusions. Although it is impossible to update with the latest data, because this research deeply investigates micro-enterprises, that can be compensated in terms of research depth and innovation. This is why there are still many high-quality papers published in the industrial enterprise database today. If the database of industrial enterprises can be updated in the future, the long-term industrial investment impact of the above policies can be more comprehensively measured and investigated over a longer time dimension.

\section{Conclusions and Policy Suggestions}

\subsection{Conclusions}

As China's reform has entered a critical stage, the market-oriented reform of factors has been elevated to an important strategic position. As noted at the beginning of this paper, in the first half of 2020, the Central Committee of the Communist Party of China and the State Council successively issued two important documents to promote the reform of factor marketization, and the reform of land marketization is an important part. Industrial land is an important carrier to ensure industrial development, and the steady advancements in the reform of its market-oriented allocation and optimization of its mechanism are of great significance to China's industrial upgrading and high-quality economic development. Therefore, after the reform has been implemented for a period of time, a review and analysis of its effectiveness will provide an important reference for the next step of deepening it.

Based on this, this paper examined the impact of market reform of industrial land on land prices by constructing a database of corporate land purchases, and further analyzed local governments' strategic choice of land transfer modes and the resulting land price subsidy effects against the background of the reform. This research shows the following:

With the continuous deepening of industrial land market reform, results have gradually emerged. The study found that the ratio of market-oriented transfer of industrial land has been increasing (from 27.62\% in 2007 to $93.65 \%$ in 2019). Moreover, compared with the original negotiation mode, the three market-oriented transfer modes of tender, auction, and listing can significantly increase the price of industrial land and provide enterprises with a competitive land purchase environment. For example, at the beginning of the reform, state-owned enterprises could rely on the advantage of government-enterprise linkages to purchase industrial land at low prices through negotiation. With the advancement of the reform, the state has gradually increased control over negotiation, diminishing the advantage of state-owned enterprises. This shows that the reform has been effective and has achieved the initial goal of providing a more effective and open factor allocation platform.

In the context of the market-oriented reform of industrial land, local governments still have a strong demand for enterprise investment, so they tend to provide enterprises with hidden land subsidies through alternative channels by listing.

This paper finds that local governments will make strategic choices based on three market-oriented transfer methods, and will tend to transfer industrial land to target companies through listing. At the same time, the regression results of corporate land purchase prices show that, compared with the more market-oriented auction method, the prices of industrial land under the listing method are significantly lower, and there are land price subsidies. In addition, the regression results of the willingness to bid index also support the above conclusion; that is, taking into account capital constraints, enterprises' willingness to bid when competing for land through listing is significantly lower than that through auction.

In the government's strategic choice of transfer methods, state-owned and large and medium-sized enterprises can obtain implicit land price subsidies. Regarding the types of enterprise ownership, although state-owned enterprises have lost the advantages of purchasing land through negotiation, they are still more favored by the government when 
purchasing land through listing. The empirical results show that when the reform was launched in 2007, the marginal price to purchase land through listing was significantly higher for state-owned than non-state-owned enterprises, but by 2013, the marginal price was significantly lower for state-owned enterprises. This shows that as listing has gradually become an alternative to negotiation, state-owned enterprises have been able to obtain implicit land price subsidies through listing. Furthermore, considering the capital constraints, the willingness of state-owned enterprises to bid through listing is also significantly lower than that of other enterprises, again confirming that state-owned enterprises have advantages when purchasing land through listing and are preferred by local governments that are trying to attract investors.

In addition, the marginal land purchase prices for enterprises of different scales are also quite different. This study found that large-scale enterprises can enjoy more land subsidies through listing. Taking into account the financial constraints, land purchase prices for large and medium-sized enterprises are significantly lower than those for small enterprises. This finding supports the tendency of local governments to attract investment; that is, they prefer larger enterprises, which can make large investments in local economic growth [36].

\subsection{Policy Suggestions}

The conclusion of this paper is that the current industrial land market reform has achieved initial results, and the overall progress is in accordance with the design goals. However, due to the short period of time and the incomplete reform, there is still room for improvement. Based on the above research results, in response to the current needs of China's industrial development and the problems that exist in the market-oriented allocation of industrial land, this paper proposes the following policy recommendations:

The market-oriented reform of land elements should be adhered to, and the selection mechanism of tender, auction, and listing transfer methods should be further standardized and refined. The above results show that local governments will use a certain level of land price subsidies (against the background of marketization, such subsidies are limited to a range, and land prices must also be higher than benchmark prices) to attract investment and provide land at low prices in exchange for economic development. Is this choice beneficial to the long-term development of the regional economy? This issue needs to be further considered and studied.

However, it is undeniable that the market is still the most efficient form of resource allocation, and the above-mentioned hidden land price subsidy effect should also be based on the basic role of the market mechanism, forming a virtuous circle that is conducive to regional economic development. Therefore, on the one hand, we should adhere to the market-oriented reform of land elements, implement and update the lowest price standards for industrial land in a timely manner, and strictly review the low industrial land prices caused by the vicious competition of local governments attracting investors and the illegal transfer of industrial land by agreement. The purpose is to ensure openness, competitiveness and efficiency in industrial land transactions. On the other hand, there should be more detailed regulations on the selection mechanism of land transfer methods for local governments, which should be guided to take a long-term view and introduce industrial enterprises that are compatible with the region's long-term economic development goals to improve the industrial land transfer mechanism.

Based on optimizing the transfer mechanism of tender, auction, and listing, there should be a variety of ways to meet the needs of enterprises for land use (such as lease first and then transfer, and flexible term transfer) to solve and compensate for the existing insufficiency. The research in this paper finds that there are differences in land competition strategies of different companies. For state-owned and large and medium-sized enterprises, the competitive advantage of listing will reduce the company's expected investment costs and willingness to bid, which may further guide enterprises to find opportunities for low-cost land purchases, which is not conducive to the marketization of industrial 
land. As for small enterprises, especially small private enterprises, in the early stages of development, they are at a disadvantage in terms of product competition. Higher land transfer fees will mean greater financial pressure for such enterprises, which in turn will lead to weaker land purchasing. This will form the Matthew effect, which is not conducive to the development and industrial continuity of emerging enterprises. Therefore, based on further standardizing the existing tender, auction, and listing transfer mechanism, a flexible land transfer mechanism should be formulated for the different types and scales of enterprises. For example, under the maximum transfer period stipulated by the state, the implementation of the flexible term transfer system of lease first, then transfer will be promoted, so that enterprises can determine the appropriate land use life based on their own production and operation conditions and reduce unnecessary sunk costs. At the same time, local governments should formulate corresponding assessment indicators for enterprises within the transfer period, and enforce stricter supervision over their land use based on their subsequent production and operation activities, in order to achieve intensive use of industrial land.

Author Contributions: Conceptualization, L.Z. and Y.Z.; methodology, L.Z.; software, Y.Z. and Y.L.; validation, Y.Z., Y.L. and J.Q.; formal analysis, L.Z. and Y.Z.; investigation, Y.Z.; resources, Y.Z. and Y.L.; data curation, Y.Z. and Y.L.; writing—original draft preparation, L.Z.; writing—review and editing, L.Z., Y.Z. and Y.L.; visualization, Y.Z.; supervision, L.Z.; project administration, L.Z.; funding acquisition, L.Z. All authors have read and agreed to the published version of the manuscript.

Funding: This research was funded by "The National Social Science of Foundation of China" (grant number 20BGL184), "The Foundation of Humanity and Social Sciences of the Ministry of Education" (grant number 18YJA790106). Economic and Social Development Project of Liaoning Province: 2022lslybkt-017.

Data Availability Statement: The data sources involved in this paper were clearly pointed out in the text.

Conflicts of Interest: The authors declare no conflict of interest.

\section{Appendix A}

Appendix A.1. Results of Mlogit Model Considering Types of Enterprises (2007-2013)

In Section 5.2, using a multivariate logit model, we estimated the probability of land purchase by tender, auction, and listing relative to negotiation. The purpose is to explore the intention of local governments to transfer industrial land to different enterprises under the background of market-oriented reform, and the preference of local governments to choose the way of transfer. Due to the limited space of the text, the regression results of the intermediate years have not been reported, which are now reported in the Appendix A.

Table A1. Results of mlogit model considering types of enterprises (2007-2009).

\begin{tabular}{|c|c|c|c|c|c|c|c|c|c|}
\hline \multirow{2}{*}{ Variables } & \multicolumn{3}{|c|}{2007} & \multicolumn{3}{|c|}{2008} & \multicolumn{3}{|c|}{2009} \\
\hline & (1) Tender & (2) Auction & (3) Listing & (4) Tender & (5) Auction & (6) Listing & (7) Tender & (8) Auction & (9) Listing \\
\hline state-owned & 0.1263 & -1.1908 & -0.0251 & -0.1141 & -0.3491 & $-0.8131^{* * *}$ & $-0.8590 *$ & $-0.8851 * *$ & $-0.6413^{* * *}$ \\
\hline enterprise & $(0.3055)$ & $(-1.1523)$ & $(-0.1587)$ & $(-0.2772)$ & $(-0.6397)$ & $(-4.7721)$ & $(-1.7582)$ & $(-2.1129)$ & $(-3.7620)$ \\
\hline HKMT & -14.7584 & -0.6408 & -0.1578 & $0.9406 * *$ & -0.0508 & -0.0766 & -0.9949 & $-2.3300 * *$ & -0.0485 \\
\hline enterprise & $(-0.0189)$ & $(-0.6224)$ & $(-0.7812)$ & $(2.1811)$ & $(-0.0666)$ & $(-0.3138)$ & $(-1.3239)$ & $(-2.2664)$ & $(-0.2067)$ \\
\hline foreign & -0.0004 & -0.6493 & 0.2365 & 0.0770 & -12.9612 & 0.2475 & -0.3198 & -0.6492 & -0.1507 \\
\hline enterprise & $(-0.0009)$ & $(-0.6277)$ & $(1.4430)$ & $(0.1341)$ & $(-0.0257)$ & $(1.0060)$ & $(-0.6329)$ & $(-1.3985)$ & $(-0.7104)$ \\
\hline Controls & yes & yes & yes & yes & yes & yes & yes & yes & yes \\
\hline Constant & $\begin{array}{l}-18.5791{ }^{*} \\
(-1.9547)\end{array}$ & $\begin{array}{c}-49.8848^{* * *} \\
(-3.8758)\end{array}$ & $\begin{array}{c}-42.4574 \text { *** } \\
(-12.5890)\end{array}$ & $\begin{array}{c}-32.5082^{* * *} \\
(-3.0691)\end{array}$ & $\begin{array}{c}-36.0056^{* * *} \\
(-3.1274)\end{array}$ & $\begin{array}{l}-1.8145 \\
(-0.4951)\end{array}$ & $\begin{array}{c}-22.4932 * * \\
(-2.4568)\end{array}$ & $\begin{array}{c}-7.7541 \\
(-1.0649)\end{array}$ & $\begin{array}{l}-5.6689 \\
(-1.5875)\end{array}$ \\
\hline $\mathrm{N}$ & 3480 & $\begin{array}{c}(-5.0700) \\
3480\end{array}$ & 3480 & 3013 & 3013 & 3013 & $\begin{array}{l}4.4300) \\
4139\end{array}$ & 4139 & 4139 \\
\hline Pseudo R2 & 0.0837 & 0.0837 & 0.0837 & 0.0868 & 0.0868 & 0.0868 & 0.0806 & 0.0806 & 0.0806 \\
\hline
\end{tabular}

Note: Z-statistics in parentheses; ${ }^{* *} p<0.01,{ }^{* *} p<0.05,{ }^{*} p<0.1$. Controls are a set of control variables including parcel_resource, region, $\ln P G D P$, industrial_structure, Intraffic, Inwage, expenditure. 
Table A2. Results of mlogit model considering types of enterprises (2010-2012).

\begin{tabular}{|c|c|c|c|c|c|c|c|c|c|}
\hline \multirow[b]{2}{*}{ Variables } & \multicolumn{3}{|c|}{2010} & \multicolumn{3}{|c|}{2011} & \multicolumn{3}{|c|}{2012} \\
\hline & $\begin{array}{c}\text { (10) } \\
\text { Tender }\end{array}$ & $\begin{array}{c}\text { (11) } \\
\text { Auction }\end{array}$ & $\begin{array}{c}\text { (12) } \\
\text { Listing }\end{array}$ & $\begin{array}{c}\text { (13) } \\
\text { Tender }\end{array}$ & $\begin{array}{c}\text { (14) } \\
\text { Auction }\end{array}$ & $\begin{array}{c}\text { (15) } \\
\text { Listing }\end{array}$ & $\begin{array}{c}\text { (16) } \\
\text { Tender }\end{array}$ & $\begin{array}{c}\text { (17) } \\
\text { Auction }\end{array}$ & $\begin{array}{c}(18) \\
\text { Listing }\end{array}$ \\
\hline state-owned & -16.0256 & $-1.3704^{* * *}$ & $-0.9505^{* * *}$ & -0.8982 & $-0.7871^{* * *}$ & -1.0650 *** & -16.0859 & $-0.7880 * *$ & $-0.9155^{* * *}$ \\
\hline enterprise & $(-0.0114)$ & $(-3.0740)$ & $(-5.9129)$ & $(-0.8522)$ & $(-2.7203)$ & $(-7.5332)$ & $(-0.0072)$ & $(-2.5716)$ & $(-5.5432)$ \\
\hline HKMT & -15.0106 & -0.0774 & -0.0594 & 1.2032 & -0.2027 & 0.1288 & 0.5459 & 0.0436 & -0.0526 \\
\hline enterprise & $(-0.0082)$ & $(-0.1586)$ & $(-0.2267)$ & (1.4948) & $(-0.4620)$ & $(0.4584)$ & $(0.6230)$ & $(0.1118)$ & $(-0.1831)$ \\
\hline Foreign & -15.4049 & -0.3550 & 0.0647 & 1.4555 * & 0.5212 & 0.0260 & -16.8571 & 0.1105 & $-0.6640 * * *$ \\
\hline enterprise & $(-0.0098)$ & $(-0.6931)$ & $(0.2746)$ & (1.7590) & (1.5309) & $(0.1000)$ & $(-0.0051)$ & $(0.3655)$ & $(-2.8407)$ \\
\hline Controls & yes & yes & yes & yes & yes & yes & yes & yes & yes \\
\hline \multirow[t]{2}{*}{ Constant } & -73.8862 & 1.6470 & 3.8386 & $-52.1165^{* * *}$ & $21.5522^{* * *}$ & -5.1855 & -4.2607 & $25.3062 * * *$ & $\underset{* * *}{-14.9683}$ \\
\hline & $(-0.0730)$ & $(0.1816)$ & $(0.8599)$ & $(-3.1513)$ & $(3.4544)$ & $(-1.4852)$ & $(-0.0055)$ & (3.9643) & $(-3.6738)$ \\
\hline $\mathrm{N}$ & 3212 & 3212 & 3212 & 8143 & 8143 & 8143 & 8788 & 8788 & 8788 \\
\hline Pseudo R2 & 0.1199 & 0.1199 & 0.1199 & 0.1024 & 0.1024 & 0.1024 & 0.0992 & 0.0992 & 0.0992 \\
\hline
\end{tabular}

Note: Z-statistics in parentheses; ${ }^{* *} p<0.01,{ }^{* *} p<0.05,{ }^{*} p<0.1$. Controls are a set of control variables including parcel_resource, region, lnPGDP, industrial_structure, lntraffic, lnwage, expenditure.

In terms of different types of enterprises, the results in Tables A1-A3 show that the coefficients of HKMT enterprise and foreign enterprise are not significant from 2007 to 2013, while the coefficient of state-owned enterprise by auction and listing has been significantly negative since 2009. This indicates that, compared with the reference group (other mainland enterprise), the probability of state-owned enterprises acquiring industrial land by negotiation is still higher. Secondly, by comparing the probability of enterprises acquiring land by auction and listing, it can be found that since 2009, the coefficient of state-owned enterprises by auction is first smaller than that by listing, then larger than that by listing, and finally smaller than that by listing. This means that under the background of market-oriented reform, the possibility of state-owned enterprises purchasing land by listing and auction fluctuates constantly, and the possibility of purchasing land by listing is higher than auction.

Table A3. Results of mlogit model considering types of enterprises (2013).

\begin{tabular}{cccc}
\hline \multirow{2}{*}{ Variables } & \multicolumn{3}{c}{$\mathbf{2 0 1 3}$} \\
\cline { 2 - 4 } & $\mathbf{( 1 9 )}$ Tender & $\mathbf{( 2 0 ) \text { Auction }}$ & (21) Listing \\
\hline state-owned enterprise & -15.9014 & $-1.5444^{* * *}$ & $-1.4455^{* * *}$ \\
HKMT enterprise & $(-0.0114)$ & $(-5.3158)$ & $(-9.6817)$ \\
foreign enterprise & -15.4280 & -0.1884 & -0.1990 \\
& $(-0.0080)$ & $(-0.5001)$ & $(-0.7083)$ \\
Controls & -14.7895 & 0.4711 & $0.6080^{*}$ \\
Constant & $(-0.0084)$ & $(1.1322)$ & yes \\
& yes & yes & $-9.5428^{* * *}$ \\
N & 7.1719 & $27.0223 * * *$ & $(-2.5882)$ \\
Pseudo R2 & $(0.0066)$ & $(4.9683)$ & 10,449 \\
& 10,449 & 10,449 & 0.1112
\end{tabular}

Note: Z-statistics in parentheses; ${ }^{* * *} p<0.01,{ }^{*} p<0.1$. Controls are a set of control variables including parcel_resource, region, InPGDP, industrial_structure, lntraffic, lnwage, expenditure.

To further test the robustness of the empirical results, mlogit regression is performed based on the data from 2007 to 2013, and the results are listed in Table A4. The results show that, the coefficient of state-owned enterprise by auction is lower than that by listing. This indicates that, after the market-oriented reform, the possibility of state-owned enterprises purchasing land by listing is significantly higher than auction. The result is consistent with the regression result of the text and supports Hypothesis 2, which verifies that in the market-oriented transfer of industrial land, local governments tend to choose listing to transfer industrial land to state-owned enterprises. 
Table A4. Results of mlogit model considering types of enterprises (2007-2013).

\begin{tabular}{cccc}
\hline Variables & (1) Tender & (2) Auction & (3) Listing \\
\hline state-owned enterprise & $-0.6647^{* * *}$ & $-1.1702^{* * * *}$ & $-1.0142^{* * * *}$ \\
HKMT enterprise & $(-2.8587)$ & $(-8.6981)$ & $(-18.1584)$ \\
foreign enterprise & -0.3052 & $-0.5510^{* * *}$ & $-0.2511^{* * * *}$ \\
& $(-1.1096)$ & $(-3.4477)$ & $(-3.3545)$ \\
Controls & $-0.4496^{*}$ & $-0.2569^{*}$ & $-0.3282^{* * *}$ \\
Constant & $(-1.6834)$ & $(-1.9529)$ & $(-4.6829)$ \\
& yes & yes & yes \\
N & $-13.8087^{* * *}$ & $-37.0181^{* * *}$ & $-50.1600^{* * *}$ \\
Pseudo R2 & $(-3.8130)$ & $(-20.2369)$ & $(-50.5844)$ \\
& 41,224 & 41,224 & 41,224 \\
& 0.1292 & 0.1292 & 0.1292 \\
\hline
\end{tabular}

Note: Z-statistics in parentheses; ${ }^{* * *} p<0.01,{ }^{*} p<0.1$. Controls are a set of control variables including parcel_resource, region, InPGDP, industrial_structure, Intraffic, lnwage, expenditure.

\section{Appendix A.2. Results of Mlogit Model Considering Scale of Enterprises (2007-2013)}

Tables A5-A7 report the results of the annual mlogit regression considering scale of enterprises for 2007-2013. The results show that from the comparison of scale of enterprises, in the early stage of reform in 2007, the coefficients of large-scale enterprises by auction and listing were not significant, but with the deepening of reform, since 2011, the coefficients of large-scale enterprises by auction and listing have been significantly negative. This indicates that larger enterprises have a higher probability of purchasing land by negotiation, confirming that large-scale enterprises are the preferred enterprises of local governments. Besides, the coefficients of large-scale enterprises by auction are all lower than listing, and pass the significance test of $1 \%$, indicating that large enterprises are also more likely to purchase land by listing than auction. This is consistent with the regression results of the text, indicating that under the background of market-oriented reform, when local governments need to transfer industrial land by market-oriented methods, they tend to choose listing to transfer industrial land to large-scale enterprises.

The results of mlogit model considering types and scale of enterprises mentioned above verify the robustness of conclusion again. In the context of the market-oriented reform of industrial land, local governments will choose listing as an alternative to the negotiation to transfer industrial land to their preferred enterprises (state-owned enterprises and large-scale enterprises).

Table A5. Results of mlogit model considering scale of enterprises (2007-2009).

\begin{tabular}{|c|c|c|c|c|c|c|c|c|c|}
\hline \multirow{2}{*}{ Variables } & \multicolumn{3}{|c|}{2007} & \multicolumn{3}{|c|}{2008} & \multicolumn{3}{|c|}{2009} \\
\hline & (1) Tender & (2) Auction & (3) Listing & (4) Tender & (5) Auction & (6) Listing & (7) Tender & (8) Auction & (9) Listing \\
\hline large-scale & 0.0676 & 0.3117 & 0.0543 & 0.2172 & 0.3034 & $-0.2650 *$ & 0.1507 & $-0.7904 * *$ & 0.0182 \\
\hline enterprise & $(0.1788)$ & $(0.5382)$ & $(0.3885)$ & $(0.5976)$ & $(0.6977)$ & $(-1.7266)$ & $(0.4839)$ & $(-2.3441)$ & $(0.1237)$ \\
\hline medium-scale & -0.3627 & 0.2934 & -0.0765 & 0.2862 & 0.2770 & 0.0096 & -0.1670 & -0.1945 & 0.1156 \\
\hline enterprise & $(-1.3388)$ & $(0.7519)$ & $(-0.8328)$ & (1.0505) & $(0.8959)$ & $(0.0872)$ & $(-0.6831)$ & $(-0.9908)$ & $(1.0756)$ \\
\hline Controls & yes & yes & yes & yes & yes & yes & yes & yes & yes \\
\hline Constant & $-19.1288^{* *}$ & $-51.1120^{* * *}$ & $-42.3113^{* * *}$ & $-31.3505^{* * *}$ & $-35.8917^{* * *}$ & -0.7029 & $-23.1481^{* *}$ & -9.7473 & -5.3080 \\
\hline & $(-2.0341)$ & $(-3.9769)$ & $(-12.5907)$ & $(-2.9879)$ & $(-3.1232)$ & $(-0.1932)$ & $(-2.5515)$ & $(-1.3392)$ & $(-1.4964)$ \\
\hline $\mathrm{N}$ & 3480 & 3480 & 3480 & 3013 & 3013 & 3013 & 4139 & 4139 & 4139 \\
\hline Pseudo R2 & 0.0817 & 0.0817 & 0.0817 & 0.0799 & 0.0799 & 0.0799 & 0.0775 & 0.0775 & 0.0775 \\
\hline
\end{tabular}

Note: Z-statistics in parentheses; ${ }^{* * *} p<0.01,{ }^{* *} p<0.05,{ }^{*} p<0.1$. Controls are a set of control variables including parcel_resource, region, lnPGDP, industrial_structure, lntraffic, lnwage, expenditure. 
Table A6. Results of mlogit model considering scale of enterprises (2010-2012).

\begin{tabular}{|c|c|c|c|c|c|c|c|c|c|}
\hline \multirow[b]{2}{*}{ Variables } & \multicolumn{3}{|c|}{2010} & \multicolumn{3}{|c|}{2011} & \multicolumn{3}{|c|}{2012} \\
\hline & $\begin{array}{c}\text { (10) } \\
\text { Tender }\end{array}$ & $\begin{array}{c}\text { (11) } \\
\text { Auction }\end{array}$ & $\begin{array}{c}\text { (12) } \\
\text { Listing }\end{array}$ & $\begin{array}{c}\text { (13) } \\
\text { Tender }\end{array}$ & $\begin{array}{c}\text { (14) } \\
\text { Auction }\end{array}$ & $\begin{array}{c}\text { (15) } \\
\text { Listing }\end{array}$ & $\begin{array}{c}\text { (16) } \\
\text { Tender }\end{array}$ & $\begin{array}{c}\text { (17) } \\
\text { Auction }\end{array}$ & $\begin{array}{c}\text { (18) } \\
\text { Listing }\end{array}$ \\
\hline $\begin{array}{l}\text { large-scale } \\
\text { enterprise }\end{array}$ & $\begin{array}{c}-0.4528 \\
(-0.4209)\end{array}$ & $\begin{array}{c}-0.0481 \\
(-0.1283)\end{array}$ & $\begin{array}{c}-0.0138 \\
(-0.0687)\end{array}$ & $\begin{array}{c}0.4376 \\
(0.5989)\end{array}$ & $\begin{array}{c}-0.6512 * * * \\
(-2.8295)\end{array}$ & $\begin{array}{c}-0.5301 * * * \\
(-3.7874)\end{array}$ & $\begin{array}{l}-15.8627 \\
(-0.0125)\end{array}$ & $\begin{array}{c}-0.8002 * * * \\
(-3.6405)\end{array}$ & $\begin{array}{c}-0.7656^{* * *} \\
(-5.2071)\end{array}$ \\
\hline $\begin{array}{c}\text { medium-scale } \\
\text { enterprise }\end{array}$ & $\begin{array}{l}-0.0516 \\
(-0.0980)\end{array}$ & $\begin{array}{c}-0.3192 \\
(-1.3256)\end{array}$ & $\begin{array}{l}-0.2278 * \\
(-1.8479)\end{array}$ & $\begin{array}{c}0.8668 \\
(1.4998)\end{array}$ & $\begin{array}{c}-0.1626 \\
(-0.9498)\end{array}$ & $\begin{array}{l}-0.2428^{* *} \\
(-2.1647)\end{array}$ & $\begin{array}{c}0.6665 \\
(0.8323)\end{array}$ & $\begin{array}{c}-0.1992 \\
(-1.1914)\end{array}$ & $\begin{array}{c}-0.3101 * * * \\
(-2.5860)\end{array}$ \\
\hline Controls & yes & yes & yes & yes & yes & yes & yes & yes & yes \\
\hline Constant & $\begin{array}{l}-71.5600 \\
(-0.1473)\end{array}$ & $\begin{array}{c}4.0199 \\
(0.4481)\end{array}$ & $\begin{array}{c}5.8358 \\
(1.3224)\end{array}$ & $\begin{array}{c}-50.8451 * * * \\
(-3.0739)\end{array}$ & $\begin{array}{c}23.2573 * * * \\
(3.7327)\end{array}$ & $\begin{array}{c}-3.6917 \\
(-1.0625)\end{array}$ & $\begin{array}{c}2.6450 \\
(0.0036)\end{array}$ & $\begin{array}{c}26.9776 * * * \\
(4.2300)\end{array}$ & $\begin{array}{c}-13.3949 * * * \\
(-3.2933)\end{array}$ \\
\hline $\mathrm{N}$ & 3212 & 3212 & 3212 & 8143 & 8143 & 8143 & 8788 & 8788 & 8788 \\
\hline Pseudo R2 & 0.1093 & 0.1093 & 0.1093 & 0.0965 & 0.0965 & 0.0965 & 0.0978 & 0.0978 & 0.0978 \\
\hline
\end{tabular}

Note: Z-statistics in parentheses; ${ }^{* *} p<0.01,{ }^{* *} p<0.05,{ }^{*} p<0.1$. Controls are a set of control variables including parcel_resource, region, lnPGDP, industrial_structure, Intraffic, lnwage, expenditure.

Table A7. Results of mlogit model considering scale of enterprises (2013).

\begin{tabular}{cccc}
\hline \multirow{2}{*}{ Variables } & \multicolumn{3}{c}{$\mathbf{2 0 1 3}$} \\
\cline { 2 - 4 } & $\mathbf{( 1 9 )}$ Tender & (20) Auction & (21) Listing \\
\hline large-scale enterprise & $-2.1653^{*}$ & $-0.9138^{* * *}$ & $-0.4563^{* * *}$ \\
medium-scale enterprise & $(-1.9444)$ & $(-4.2792)$ & $(-3.1774)$ \\
& -0.1063 & -0.2150 & $-0.1964^{*}$ \\
Controls & $(-0.2138)$ & $(-1.3999)$ & $(-1.6923)$ \\
Constant & yes & yes & yes \\
& 13.3978 & $28.2626^{* * *}$ & $-8.3418^{* *}$ \\
N & $(0.0184)$ & $(5.1914)$ & $(-2.2657)$ \\
Pseudo R2 & 10,449 & 10,449 & 10,449 \\
& 0.1033 & 0.1033 & 0.1033 \\
\hline
\end{tabular}

Note: Z-statistics in parentheses; ${ }^{* * *} p<0.01,{ }^{* *} p<0.05,{ }^{*} p<0.1$. Controls are a set of control variables including parcel_resource, region, lnPGDP, industrial_structure, lntraffic, lnwage, expenditure.

Appendix A.3. Influence of Choice of Land Transfer Mode by Local Governments on Enterprises' Willingness to Bid

In Section 5.4, based on the willingness of enterprises to bid, we firstly discuss the influence of different transfer mode of local governments on the willingness of enterprises to bid. Due to the limited space of the text, the intermediate years are not reported, which is now reported here.

The regression results by year are reported in Table A8. The results show that the coefficients of auction and listing are significantly positive from 2007 to 2013 . While the significance of coefficients of listing fluctuates, they are also significantly positive from 2011 to 2013, which is consistent with the text results, proving that compared with the negotiation, market-oriented transfer modes is conducive to the improvement of the bidding willingness of enterprises.

Furthermore, by comparing the coefficients of auction and listing in each year, it can be found that, with the deepening of reform, the coefficients of auction are all higher than those of listing since 2009, which indicates that under the background of market-oriented reform, the bidding willingness of enterprises to purchase land by listing is significantly lower than that by auction. This is consistent with the results of the text, which further shows that local governments can give certain implicit subsidies to enterprises through listing, and this behavior gradually appears with the deepening of reform. 
Table A8. Influence of industrial land transfer modes on enterprises' willingness to bid (2007-2013).

\begin{tabular}{|c|c|c|c|c|c|c|c|}
\hline Variables & (1) 2007 & (2) 2008 & (3) 2009 & (4) 2010 & (5) 2011 & (6) 2012 & (7) 2013 \\
\hline \multirow[t]{2}{*}{ tender } & 0.1090 & $0.6395^{* * *}$ & $0.4468^{* * *}$ & 0.4890 & $0.5540 * *$ & $1.4188^{* * *}$ & $1.0439 * * *$ \\
\hline & $(0.2118)$ & $(0.2045)$ & $(0.1670)$ & $(0.3369)$ & $(0.2333)$ & $(0.2389)$ & $(0.3468)$ \\
\hline \multirow[t]{2}{*}{ auction } & $0.4057^{*}$ & 0.2672 & $1.0596^{* * *}$ & $1.0491^{* * *}$ & $0.8632^{* * *}$ & $0.9271^{* * *}$ & $0.8090^{* * *}$ \\
\hline & $(0.2401)$ & $(0.2292)$ & $(0.1453)$ & $(0.1712)$ & $(0.1262)$ & $(0.1124)$ & (0.1097) \\
\hline \multirow{2}{*}{ listing } & $0.3702^{* * *}$ & $0.5993^{* * *}$ & $0.6570^{* * *}$ & $0.6891^{* * *}$ & $0.8102^{* * *}$ & $0.7605^{* * *}$ & $0.6175^{* * *}$ \\
\hline & $(0.0665)$ & $(0.0845)$ & $(0.0861)$ & $(0.1028)$ & $(0.0850)$ & $(0.0844)$ & $(0.0836)$ \\
\hline Controls & Yes & Yes & Yes & Yes & Yes & Yes & Yes \\
\hline \multirow[t]{2}{*}{ Constant } & $9.7951^{* * *}$ & $11.2713^{* * *}$ & $17.9157^{* * *}$ & 0.0912 & $10.3046^{* * *}$ & $11.6093^{* * *}$ & $13.0959 * * *$ \\
\hline & $(2.1328)$ & (2.1783) & (1.8808) & $(2.6248)$ & $(1.3325)$ & $(1.2877)$ & (1.1872) \\
\hline $\mathrm{N}$ & 3480 & 3013 & 4139 & 3212 & 8143 & 9117 & 10,449 \\
\hline $\mathrm{R} 2$ & 0.1255 & 0.1179 & 0.1127 & 0.2687 & 0.1136 & 0.0776 & 0.0938 \\
\hline
\end{tabular}

Note: Robust standard errors in parentheses; ${ }^{* * *} p<0.01,{ }^{* *} p<0.05,{ }^{*} p<0.1$. Controls are a set of control variables including type of enterprises, parcel_resource, region, lnPGDP, industrial_structure, Intraffic, lnwage, expenditure.

\section{Notes}

1 There are two reasons why this paper uses enterprise data provided by the database of Chinese industrial enterprises for empirical analysis. First, the database is published by the National Bureau of Statistics of China, so the source is authoritative and reliable. Second, the number of enterprises included in the database is very large (hundreds of thousands of pieces of data every year), and the business indicators are relatively comprehensive, so it can be better used in this research. However, since the official database is updated only to 2013, the final data after matching are from 2007 to 2013. This did not affect the scientificity of the research conclusions, and the impact and lag effect of market reform can still be investigated through empirical research.

2 The basic assumptions of the income equivalence principle include the following: all participants are risk-neutral, private values are independent among bidders, the bidders are symmetrical, there is no entry cost and no repeat entry, and there is no collusion.

3 The data used in Figure 1 are industrial land transfers that matched before, and the sample interval is 2007-2019.

4 The data used are the data of industrial land transfer that matched before. In order to avoid extreme values, the data were winsorized at the 1 and $99 \%$ levels.

5 Although land transfer data can be updated to the latest year, the official database of industrial enterprises is only updated to 2013 (China's microeconomic data query system can query the database for 2014, but the data quantity and quality are poor). Therefore, the matched database only dated back to 2013, but this length of time is enough to meet the analysis requirements of the research.

6 Since the database of Chinese industrial enterprises only includes state-owned enterprises and non-state-owned industrial enterprises above a designated size, the classification of large, medium, and small enterprises in this paper is a relative classification within this group.

7 For example, in 2013, the amount of industrial land transfer by tender in China was less than the $5 \%$ of auction and $0.2 \%$ of listing.

\section{References}

1. Needham, B.; Louw, E.; Metzemakers, P. An economic theory for industrial land policy. Land Use Policy 2013, 33, 227-234. [CrossRef]

2. Weber, A. Theory of the location of industries. Nature 1960, 15, 1. [CrossRef]

3. Marshall, A. Principles of economics. Political Sci. Q. 1961, 31, 430-444. [CrossRef]

4. Alonso, W. Location and land use: Toward a general theory of land rent. Econ. Geogr. 1966, 42, 277-279. [CrossRef]

5. Kowalski, J.G.; Paraskevopoulos, C.C. The impact of location on urban industrial land prices. J. Urban Econ. 1990, 27, 16-24. [CrossRef]

6. Saz-Salazar, S.D.; García-Menéndez, L. Public provision versus private provision of industrial land: A hedonic approach. Land Use Policy 2005, 22, 215-223. [CrossRef]

7. Huang, Z.; Du, X. Government intervention and land misallocation: Evidence from China. Cities 2017, 60, 323-332. [CrossRef]

8. Li, L.; Huang, P.; Ma, G. The mismatch of land resources and the productivity difference of Chinese industrial enterprises. Manag. World 2016, 8, 86-96. [CrossRef]

9. Liu, J.; Jiang, Z.; Chen, W. Land misallocation and urban air quality in China. Environ. Sci. Pollut. Res. 2021. [CrossRef]

10. Xu, Z.; Huang, J.; Jiang, F. Subsidy competition, industrial land price distortions and overinvestment: Empirical evidence from China's manufacturing enterprises. Appl. Econ. 2017, 49, 4851-4870. [CrossRef]

11. Cai, H.; Henderson, J.V.; Zhang, Q. China's land market auctions: Evidence of corruption? Rand J. Econ. 2013, 44, 488-521. [CrossRef] 
12. Wang, Y.; Yang, G. Intervention for economic growth: An analysis of local government's land transfer strategy. Manag. World 2016, 5, 18-31. [CrossRef]

13. Zhang, L.; Gao, Y.; Xu, X. Land transfer under the collusion of government and enterprise. Manag. World 2013, 12, 43-51, 62. [CrossRef]

14. Tang, P.; Shi, X.; Qu, F. Local government competition and land financial strategies. Resour. Sci. 2014, 4, 702-711.

15. Riley, J.G.; Samuelson, W.G. Optimal auctions. Am. Econ. Rev. 1981, 71, 381-392. [CrossRef]

16. Muerson, R.B. Optimal auction design. Math. Oper. Res. 1981, 6, 58-73. [CrossRef]

17. Wang, Y.; Hui, E. Are local governments maximizing land revenue? Evidence from China. China Econ. Rev. 2019, 43, 196-215. [CrossRef]

18. Rezende, L. Mid-auction information acquisition. Econ. Theory 2018, 65, 751-780. [CrossRef]

19. Compte, O.; Jehiel, P. Auctions and information acquisition: Sealed bid or dynamic formats? Rand J. Econ. 2007, 38, 355-372. [CrossRef]

20. Gretschko, V.; Rajko, A. Excess information acquisition in auctions. Exp. Econ. 2015, 18, 335-355. [CrossRef]

21. Zhou, F.; Yang, J. Does marketization improve government resource allocation efficiency-A study based micro land leasing data. Econ. Theory Bus. Manag. 2020, 2, 24-39.

22. Tu, F.; Ge, J.; Liu, D.; Zhong, Q. Determinants of industrial land price in the process of land marketization reform in China. China Land Sci. 2017, 12, 33-41.

23. Zhao, Y. Theoretical and empirical comparison of different land transfer method: Based on auction theory. Nankai Econ. Stud. 2012, 4, 97-112. [CrossRef]

24. Xu, J.; Yeh, A.; Wu, F. Land commodification: New land development and politics in China since the late 1990s. Int. J. Urban Reg. Res. 2009, 33, 890-913. [CrossRef]

25. Yang, C.; Wu, Y.; Shan, L. Political connections, anti-corruption and land leasing prices: Empirical study based on micro land transaction data. Econ. Rev. 2019, 2, 140-153. [CrossRef]

26. Wu, W.; Zhang, X.; Skitmore, M.; Song, Y.; Hui, E. Industrial land price and its impact on urban growth: A Chinese Case Study. Land Use Policy 2014, 36, 199-209. [CrossRef]

27. Sun, W.; Song, Z.; Xia, Y. Government-enterprise collusion and land supply structure in Chinese cities. Cities 2020, 105, 102849. [CrossRef]

28. Zhao, W.; Yang, J. The financial gap of local government and the way of land transfer: Based on the interpretation of mutually beneficial behaviors between local government and state-owned enterprises. Manag. World 2015, 4, 11-24. [CrossRef]

29. Tao, R.; Yuan, F.; Cao, G. Regional competition, land transfer and local fiscal effects: An analysis based on panel data of prefecture-level cities in China from 1999 to 2003. World Econ. 2007, 10, 15-27.

30. Lin, Y.; Qin, Y.; Yang, Y.; Zhu, H. Can price regulation increase land-use intensity? Evidence from China's industrial land market. Reg. Sci. Urban Econ. 2020, 81, 103501. [CrossRef]

31. Xu, S.; Chen, J.; Zhao, G. How does the land leasing marketization affect the economic growth. China Ind. Econ. 2018, 3, 44-61. [CrossRef]

32. Tao, K.; Zhang, M.; Li, L. Market reform and illegal action:Evidence from China's land lawbreaking. Nankai Econ. Stud. 2010, 2, 28-43. [CrossRef]

33. Henderson, V.; Becker, R. Political economy of city sizes and formation. J. Urban Econ. 2000, 48, 453-484. [CrossRef]

34. Zhang, L.; Wang, X.; Xu, X. Fiscal incentive, political incentive and local officials' land supply. China Ind. Econ. 2011, 4, 35-43. [CrossRef]

35. Gan, C.; Zou, J.; Wang, J. Term of local officials, enterprise resource acquisition and excess capacity. China Ind. Econ. 2015, 3, 44-56. [CrossRef]

36. Zhang, L.; Huang, L.; Liu, J. Land investment and firms' behavior-Micro evidence from industrial enterprise with purchased land. Econ. Perspect. 2019, 9, 82-96.

37. Nie, H.; Jiang, T.; Yang, R. Current status and potential problems of the use of databases in Chinese industrial enterprises. World Econ. 2012, 5, 142-158.

38. Liu, Y.; Chen, J. Land system, financing mode and industrialization with Chinese characteristics. China Ind. Econ. 2020, 3, 5-23. [CrossRef] 